University of South Florida

DIGITAL COMMONS

Digital Commons @ University of

@ UNIVERSITY OF SOUTH FLORIDA

South Florida

Integrative Biology Books

Integrative Biology

1878

\title{
Study on the Geographical Distribution of Asteroids: A Translation \\ of Étude sur la Repartition Géographique des Astérides
}

Edmond Perrier

John M. Lawrence

University of South Florida, lawr@usf.edu

Follow this and additional works at: https://digitalcommons.usf.edu/bin_books

\section{Recommended Citation}

Perrier, E. Study on the Geographical Distribution of Asteroids: A Translation of Étude sur la Repartition Géographique des Astérides (J. M. Lawrence, Trans.). Herizos Press, Tampa.

This Book is brought to you for free and open access by the Integrative Biology at Digital Commons @ University of South Florida. It has been accepted for inclusion in Integrative Biology Books by an authorized administrator of Digital Commons @ University of South Florida. For more information, please contact digitalcommons@usf.edu. 


\title{
STUDY ON THE GEOGRAPHICAL DISTRIBUTION OF ASTEROIDS
}

\author{
By \\ EDMOND PERRIER
}

Translated by

John M. Lawrence

Herizos Press

Tampa, Florida 
(C) John M. Lawrence

Herizos Press, Tampa, Florida

Translation of E. Perrier. 1878. Étude sur la repartition géographique des astérides. Nouvelles Archives du Muséum d'Histoire Naturelle. Paris. Second Series, Volume 1. 1-108. 
Perrier's work is based on the taxonomic designation of families, genera and species at that period. That taxonomy now obsolete. Perrier frequently noted misidentifications, duplications, and inadequate descriptions of species and lack of collections in many regions. He stated that future work would result in many changes. The work is of historical interest because it indicates the state of asteroid taxonomy and knowledge of asteroid distribution in the latter half of the nineteenth century.

I have retained Perrier's spelling of taxonomic names. Family name endings are sometimes inconsistent. The manuscript appears not to have been carefully proofed. There are some obvious errors. I have not attempted to correct these, but in several instances I have indicated "sic". 


\section{Edmond Perrier}
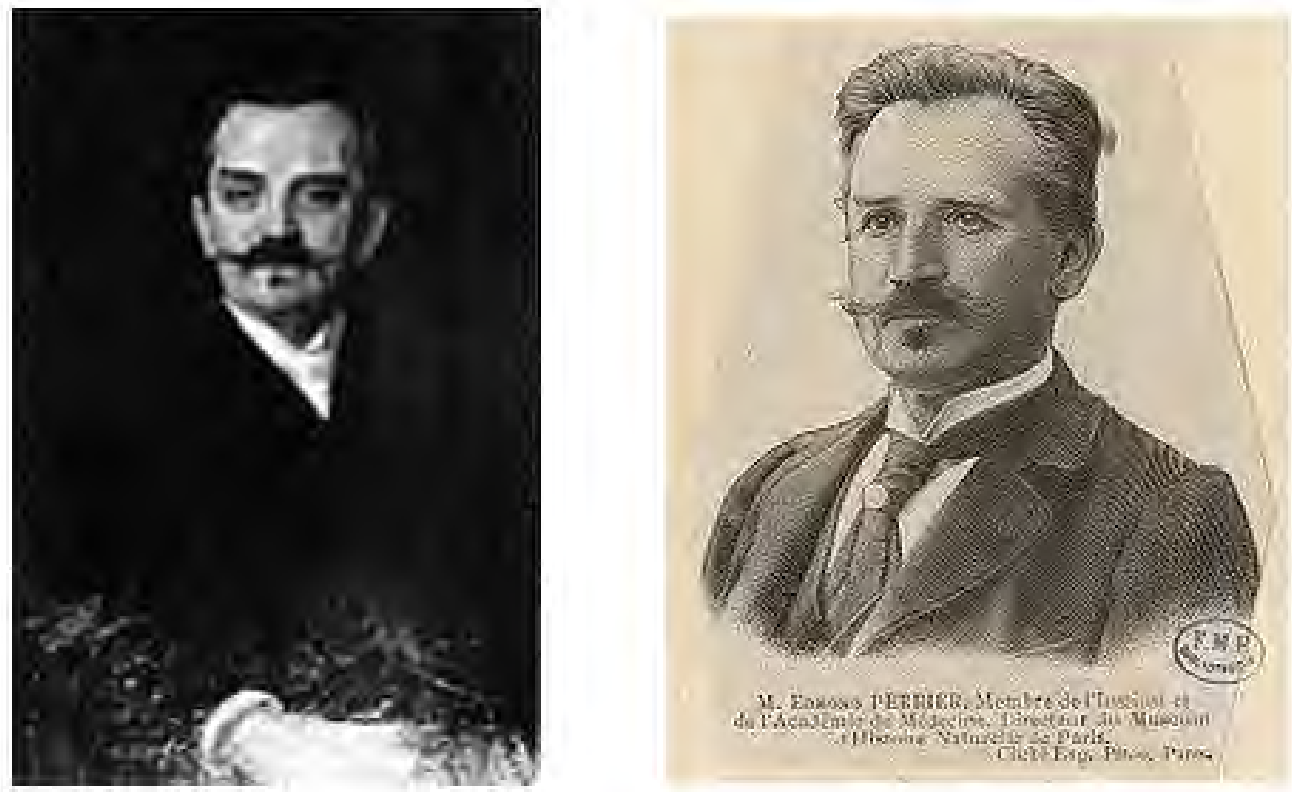

Jean Octave Edmond Perrier (9 May 1844-31 July 1921) was a student at the École Normale Supérieure, where he had classes under Henri de Lacaze-Duthiers. He earned his doctorate in 1869. He was appointed to the chair of Natural History (mollusks, worms and zoophytes) at the Muséum National d'Histoire Naturelle in 1876. He was director of the Muséum from 1900-1919.

Perrier was interested in the evolutionary theories of Lamarck and Darwin. In his study of the geographical distribution of asteroids, he stated he hoped it would contribute to arguments for or against the "doctrine of transformation". 
NOUVELLES

\title{
ARCHIVES DU MUSÉUM
}

\author{
DEUXIÈME SÉRIE
}

\section{STUDY ON THE GEOGRAPHICAL DISTRIBUTION OF ASTEROIDS}

by

EDMOND PERRIER

In the present state of science, we are especially interested in research on zoological geography regarding animals whose limited means of location force them to live in limited areas. We could suppose in fact that the effects of the environment then act on the organisms with their maximum intensity because the environment is especially all the more homogeneous as the area is itself more restricted. We investigate with care the variations in specific analogous forms that occur from one locality to another and we hope to highlight the degree of plasticity of these forms, to find incontrovertible arguments for or against the doctrine of transformation.

Terrestrial animals lend themselves in general much better than marine animals to this type of research. Among these latter, those that most abandon the benthos, those whose existence is at least temporarily pelagic are certainly the least appropriate for attempts to determine the influence of the environment. We have known for a long time that their area of distribution is in general enormous and the influence of marine currents is nearly always preponderant in their type of distribution. But why, in the same group, do we not see all the forms specific to one locality extended over the same area, why some of them remain absolutely restricted while others have a marked tendency to become cosmopolitan. What forces, what influences, what correlations between the physical world and the organism impose on some species impassible barriers and not on closely related species? These are questions whose answer is far from being reached. This is why all naturalists who seek to assemble facts to answer this question can be assured to make some service to science. On the other hand, species with a wide distribution only rarely occur, wherever they are, in identical conditions. Do they remain absolutely invariable or can we discover in them some modifications in relation to the differences in relation to the environment? This remains a question of great importance for the theory of speciation. 
From these various points of view, the history of geographical distribution of asteroids shows us some interesting facts. However, this story needs to be completed. The number of new species with each voyage adds to the catalog shows that we perhaps are far from having the final number. A very large number are still doubtful, either because the descriptions leave much to be desired or because their range is still uncertain. The origin of many others is unknown, and we cannot say, on the other hand, that our documents are sufficiently complete to fix in a definitive manner the area of distribution of some of the best known forms. Finally, we have only very few exact facts on the bathymetric distribution of these very interesting echinoderms.

Regarding the causes of the mode of dissemination of the species, care is naturally needed. In the adult state, starfish are animals with very slow locomotion: they move on the bottom of the seas but are incapable of swimming. Most of the larvae known until now are, to the contrary, pelagic. Of small size with very strong swimming structures, they can be transported great distances by currents that, in their continuous development, they sooner or later encounter. But not all are the same. The larvae of Asterina gibbosa, to which Lacaze-Duthiers has recently called attention, appears much more sedentary. It is evident a priori that the organization of the larva should have their counter effect on the area of distribution of the corresponding species. Unfortunately, the larvae of only a very few species is known. The larvae of Asterias, Cribrella, Echinaster and Asterina are known, but no one has yet reported the larval of either Linckiadae, Astropectinida, or Goniasteridae that make up however groups of great importance. We are, moreover, ignorant of the variation that can occur in the same genus.

In spite of all these gaps, in spite of all these desiderata, it is no less useful to try to synthesize the information accumulated up to now. This is the goal of this work, a natural complement to the Révision du Stellérides du Muséum that I have previously published.

\section{HISTORICAL REVIEW}

There is no comprehensive work yet published on the subject that I undertake. But eminent naturalists have carefully considered diverse local faunas. From 1780, Fabricius reported some species from Greenland in his Fauna Groënlandica. O.-F. Müller described those of the Danish coast. Since this period, the asteroids of the northern and boreal seas have been the subject of the numerous works of Düben, Koren, Michael and Ossian Sars, Steenstrup and especially Doctor Lütken, who has brought out the distinguishing characteristics of the echinoderms of Greenland, Finland, and Scandinavia and has, moreover, assembled numerous records relative to their bathymetric distribution. On the other hand, we recognize the investigations of Pennant, Fleming, Forbes, Normond on the species of Britanic seas. Unfortunately, the other published documents on the European coast of the Atlantic consist only in a work of Desmoulins, dating from 1832 and in a catalog of echinoderms of the Bay of Biscay, published in 1872 by Doctor Paul Fischer in the Actes de la Société linnéenne de Bordeaux. For the Mediterranean, the bibliography is much richer: Grube, Philippi, Michael Sars, Lorenz, Helller, and quite recently von Morenzeller, have published special studies on the echinoderm fauna of the Mediterranean and especially of the Adriatic. It is the rest of the Mediterranean that we can consider as known in this respect. We know nothing about the echinoderm fauna of the Greek archipelago, nor of the Black Sea, nor of the coasts of Asia Minor. There are probably, in this region, numerous discoveries to be made. 
Returning now to the Atlantic region situated outside the Mediterranean, we find another work reporting the voyage of Webb and Berthelot to the Canaries, in which are described some interesting new species of starfish. Nothing is known of the west coast of Africa. The east coast of this vast continent has been more studied. Peters has studied the coast of Mozambique; Michelin, those of Reunion Island; Savigny, those of the Red Sea; while von Martens has made a critical study of species of the eastern coast of Africa and those of the Sunda archipelago, the Philippines, the Celebes and the nearest Asiatic coasts.

Several years ago, Captain Hutton reported the very interesting fauna of New Zealand. He has published a very interesting catalog of the echinoderms that live on the coast of this island.

Finally, a very large number of investigators have been occupied with the asteroids of the American coasts.

Say, Gould, Desor, Stimpson, Verrill, Alexander Agassiz have successively made known the species of the coasts of the United States. Stimpson has been concerned with those of the American Pacific coast. Hupé, the great work of Claude Gay, Xantus and Philippi have described the asteroids of Chile and neighboring regions. But among all these works, we must report before all as relating in a more specific way to zoological geography the series of memoirs published by Verrill in the second volume of the Memoirs of the Society of Sciences and Arts of Connecticut.

One finds there, in addition to the numerous local lists, on which we shall have occasion to return, a careful comparison of the species of the two coasts of American, a comparison whose interest will escape no one.

Such are the most important publications that pertain to my subject. My attention in this historical review is listing all the authors who have described the asteroids in indicating their habitat. We have wanted only to recall the names of zoologist who had been concerned with the local fauna. We have, moreover, published elsewhere a bibliographic index, as complete as we have been able, of all works related to asteroids.

In the present memoir, we shall study successively the distribution of families of starfish, of genera and species. Finally, we will try to reconstitute the principal faunas characteristic of the various geographical regions.

\section{GEOGRAPHICAL DISTRIBUTION OF FAMILIES}

Starfish are found in nearly all the seas. Some species, Asterias rubens and Asterina gibbosa of our coasts, for example, extend up to the highest seas. Others to the contrary llive on in deep water, as most of the species of Pteraster, for example.

I divide the class of asteroids into eight families that are the Asteriadæ, Echinasteridæ, Linckiadæ, Goniasteridæ, Asterinidæ, Astropectinidæ, Pterasteridæ, and Brisingidæ. Each of these families has an extended geographical distribution. It is easy to see most of them have real centers around which species and genera are grouped, while genera and species become rare in other regions. We shall study the distribution of these species in the order just listed.

\section{FAMILY ASTERIADÆ}

Asteriadæ are found in the coldest regions. Asterias stellionura has been collected at Spitzberg. One finds A. polaris and Groënlandica, and Stichaster albulus that extend down the American coast to East Port (Maine). Between Iceland and Norway are Stichaster roseus, then A. hispida, A. rubens that extend to the Strait of Gibraltar but does not seem to penetrate into the Mediterranean. 
Asterias glacialis, to the contrary, is very abundant in this sea and has many varieties there. Asterias tenuispina is found in the Mediterranean like A. glacialis and extends to the Cape Verde Islands. It has also been reported at Reunion Island, but it very probable that this was a small $A$. calamaria Gray. At the Canary Islands, d'Orbigny has reported A. Webbiana, reported by Webb and Berthelot, and very close to A. glacialis, as A. Madeirenlsis, of Stimpson. But in the tropics, no species has been reported and the same fact is found on the west coast of America and the Caribbean. However, Dr. Lütken has described an Asterias Mexicana from Vera Cruz in the Gulf of Mexico. To the contrary, from Labrador to Florida, there are no less than ten species of Asteriadæ, all distinct from those on the opposite coast of the Atlantic. It is a remarkable fact that no species of this group passes from one side to the other of this ocean. These ten species are $A$. borealis and A. Fabricii of Labrador; S. albulis, A. vulgaris, liittoralis, Forbesii, tenera from the coast of Maine and from the coast of Massachusetts, A. compta, pallida and arennicola. Asteriadæ are found below the tropics. Three species are found at the Cape of Good Hope, two at Reunion, one at Madagascar. South of Australia, Tasmania and New Zealand together have ten species. Finally, I have described two of them from the Torres Strait between the most northern point of Australia and New Guinea. Only one species, A. calamaria, has been reported in the Indian Ocean. I must say, however, that I have found in the collection of the Museum, indicated as coming from Bombay, an Asterias that without this indication I would report as A. rubens. Is it an error on the label? I would not dare to say in an absolute fashion, von Martens himself having reported $A$. rubens at Japan (Yokohama and Nagasaki). It is very astonishing, if it is necessary to consider this identification as correct, because we have the right to affirm without more information that our specimen from Bombay is apocryphal. von Martens also indicated A. tenuispina as occurring at Java and the Moluccas, Hong Kong, and coast of Australia. I have already said that I believe there is confusion with small A. calamaria that reaches a much greater size than the Mediterranean species. As for Asterias striata of Lamarck, given as Asteracanthion by Mülller and Troschel, it does not belong to the genus Asteracanthion, nor even to the family Asteriadæ. It is very close to Echinaster and should be a separate genus that we have named Valvaster. I know of no Asterias from the Red Sea and that means very little, we will agree, in favor of the identity of our European species with A. tenuispina reported from Reunion Island and elsewhere by Michelin and von Martins.

In summary, there is no doubt that the tropical Atlantic region, likewise the tropical region of the Indian Ocean are not well suited to the development of Asteriadæ that are infinitely more numerous in cold and temperate regons. On the west coast of America, one genus, Heliaster, is perhaps exempted from this rule. Heliaster microbrachia and H. Kubiniji are found at Acapulco on the coast of Mexico. Now, these species and other analogues are found again at Payta, on the coast of Peru, Chile and Juan Fernandez Island. It is very probable they are found on the entire American coast from Mexico to southern Chile. Verrill reported, in fact, Heliaster microbrachia is found at Panama. It is curious to see the genus Heliaster replaced on the California coast by an apparently analogous genus, Pycnopodia of Stimpson, remarkable like the first by the multiplicity of the number of arms. Heliaster has, moreover, a very distinct physiognomy from other Asteriadæ. They are restricted to the region that we just indicated and are the only asteroids known from Central America. But at the two extremes of the tropical zone and outside, we find the same phenomenon as on the east coast. The number of species rapidly increases. 
In the Behring Strait and Sea:

$\begin{array}{cl}\text { Asterias } & \begin{array}{l}\text { acervata } \text { Stimpson } \\ \text { cribraria } \text { Stimpson }\end{array} \\ ---- & \text { Kamtschatica Brandt } \\ ---- & \text { pectinata } \text { Brandt }\end{array}$

Around Sitka Island:

$$
\begin{array}{cl}
\text { Asterias } & \text { janthina Brandt } \\
---- & \text { epichlora Brandt } \\
---- & \text { ochracea } \text { Brandt }
\end{array}
$$

Around Vancouver and in Puget Strait:

$$
\begin{array}{cl}
\text { Asterias } & \begin{array}{l}
\text { Troschelii Stimpson } \\
\text { paucispina Stimpson }
\end{array} \\
---- & \text { hexactis Stimpson } \\
---- & \text { conferta } \text { Stimpson } \\
---- & \text { Vancouveri E.P. }
\end{array}
$$

On the Oregon coast:

$$
\begin{array}{cl}
\text { Asterias } & \text { fissispina } \text { Stimpson } \\
---- & \text { gigantea } \text { Stimpson } \\
---- & \text { Katherince Gray } \\
---- & \text { Lütkenii } \text { Stimpson }
\end{array}
$$

On the California coast:

$$
\begin{array}{cl}
\text { Asterias } & \text { brevispina } \text { Stimpson } \\
---- & \text { aqualis } \text { Stimpson } \\
---- & \text { capitata } \text { Stimpson }
\end{array}
$$

Finally at Cape San Lucas at the southern end of Baja California

$$
\text { Asterias sertulifera Xanthus }
$$

Pycnopodia helianthoides seems to span more or less all these faunas. It is found from Sitka Island to the coast of Baja California.

This is a region of remarkable richness, comparatively the same as the opposite coast. Furthermore, it is among the Asteriadæ that are found species with large capitate tubercles, whose physiognomy is so characteristic and seems reproduced in a region equally very rich but located nearly at the antipodes of the preceding. I want to speak of southern Australia, Tasmania and New 
Zealand. There are no less than ten species there and among them species with very large spherical tubercles, for which Gray created the genera Margaraster and Uniophora. These are:

$\begin{array}{cl}\text { Asterias } & \text { fungifera } \text { E.P } \\ ---- & \text { globifera } \text { Gray } \\ ---- & \text { granifera Lamarck } \\ ---- & \text { sinusö̈da } \text { E.P. } \\ ---- & \text { polyplax Müller and Troschel }\end{array}$

and for New Zealand:

Asterias Mollis Hutton

--- scaber Hutton

Stichaster australis Verrill

Asterias calamaria Gray, found from Reunion Island to the western coast of Australia is replaced in this region by Asterias murciata Verrill, which is perhaps identical.

The south of America is also well represented. At Tierra del Fuego and in the Strait of Magellan are found:

$\begin{array}{cl}\text { Asterias } & \text { antarctica } \text { Lütken } \\ ---- & \text { rugispina } \text { Stimpson } \\ ---- & \text { meridionalis } \text { E.P. } \\ --- & \text { sulcifer Valenciennes } \\ ---- & \text { Cunninghami E.P. }\end{array}$

The curious Labididaster radiosus Lovén on the Patagonian coast seems to be the counterpart of Pycnopodia helianthoides of California. We do not know how far up these species extend, but on the coast of Chile they are replaced by:

$\begin{array}{ll}\text { Asterias } & \text { gelatinosa Meyen } \\ ---- & \text { gemmifer Valenciennes } \\ ---- & \text { Germamii Philippi } \\ ---- & \text { lurida } \text { Philippi } \\ --- & \text { spectabile Philippi } \\ ---- & \text { varia } \text { Philippi } \\ ---- & \text { clavata } \text { Philippi } \\ --- & \text { fulva } \text { Philippi } \\ ---- & \text { mitis } \text { Philippi } \\ ---- & \text { echinata } \text { Philippi }\end{array}$

to which can be added the beautiful Stichaster aurantiacus Meyen and Heliaster helianthus Lamarck, twelve species in all.

But this is the region of the maximum number of species. Higher up, the number of species decreases rapidly. On the coast of Peru, Verrill reports only Heliaster helianthus, Heliaster 
Cumingii Gray and Stichaster aurantiacus. Two Heliaster species are found also at the Galapagos Islands. But no asteride has been reported on the coast of Ecuador or Colombia. A single Heliaster, Heliaster microbrachia Xanthus, has been found in the Bay of Panama. So in all latitudes, the same phenomenon occurs. Species of the family Asteriadæ, more or less numerous in temperate regions, become much rarer as the warm region is approached. They belong essentially to the median zones. We will have to see by looking at the genera and species how their distribution is brought about.

\section{FAMILY ECHINASTERIDÆ}

We recognize in this family the genera Solaster, Acanthaster, Echinaster, Valvaster, Cribrella and Mithrodia. The first is perhaps more separate from the others than they are themselves from one another.

The phenomenon we just reported relative to the preceding family disappears completely. Echinasteridæ are found in the coldest seas, as well as in hot and temperate seas. The only region with no mention of any species is the west coast of Africa, from the Sahara to the Cape. von Martens does not mention any species from the coast of China, but Herklots mentions one species from Japan. This leads us to make the observation that the two regions that show this gap are precisely all the regions of the globe of which the echinoderm fauna is least known.

Indeed, the genera of the Echinasteridæ are in general more restricted than those of the Asteriadæ. Cribella and Solaster, for example, are from cold and temperate regions. Echinaster coexists on the coast of the Channel with one or the other, but they only reach their full development in the warmest regions where Acanthaster takes the place of Solaster, from which they differ only in the spines of their skeleton. Valvaster and Mithrodia are also from warm regions.

If now we consider the species in detail, we will see that they are replaced mutually in the various seas without their number changing much. Thus in all the northern part of the Atlantic, in Europe as in America, and perhaps even in the corresponding part of the Pacific, we find the following species:

$\begin{array}{cl}\text { Solaster } & \text { endeca } \text { Linck } \\ \text {---- } & \text { papposus Linck } \\ \text { Cribrella } & \text { oculata } \text { Linck }\end{array}$

Cribrella Eschrichtii is added to this list between Greenland and Labrador, while Cribrella Sarsii_Müller and Troschel and Solaster furcifer M. and T. occur in the waters of the islands off the coast of Norway.

In the Behring Strait, these species of Solaster are represented by little known species that Brandt names $S$. affinis and S. alboverrucosus and at the lower latitude of Sitka Island by Solaster endeca var. decemradiatus. Below Sitka Island, no one any longer mentions Solaster. But Stimpson has described Cribella laviuscula from the coasts of Oregon. Then Echinasteridæ disappears until the coasts of Panama. We remember, however, that this region cannot be considered as perfectly explored.

In the Atlantic, things are a little different. The fauna contines to have a northern character right up to the North Sea. But in the Channel, Solaster endeca and Solaster furcifer (the latter is, moreover, from deep water) seems to have disappeared. In compensation, Echinaster sepositus 
Retzius makes its appearance. At least, it is found on the coast of Britany. Doctor P. Fischer has encountered it in the Bay of Biscay and one can conclude it inhabits the entire French Atlantic coast. But our learned colleague does not mention in his list Cribrella oculata, which also inhabits the coasts of the Channel, and seems to not to go further down in the Atlantic, nor Solaster, of which a single species, Solaster papposus, inhabits the Channel. Echinaster sepositus penetrates into the Mediterranean where it is found nearly everywhere. It is replaced in the Red Sea, in all the Indian Ocean and off the coasts all the Asiatic archipelago by a species that has a great affinity to it, E. fallax Müller and Troschel. At the same time, Acanthaster echinites takes the place of Solaster. Echinaster gracilis M. T. and a curious species, E. vestitus E.P., is added to this one at Zanzibar, while to the north-east of Australia Echinaster eridanella Val. is found along with $E$, fallax in several localities. According to von Martens, the first of these two species extends up into the Red Sea. All these localities are inhabited at the same time by Mithrodia clavigera Lamarck. So that we find here again four species of Echinasteridæ as in cold waters. It is up to here the Mediterranean that represents the minimum of a single species. The warm and temperate regions of the east coast of America has the same conditions as our oceanic coasts.

One species, Echinaster echinophora Lamarck, occurs along the entire coast of Brazil, in the entire Caribbean Sea and the Gulf of Mexico. Higher up, below Florida, these two species are replaced by E. sentus Say and E. spinulosus Verrill.

On the west side of the Americas, there are no species of the east coast. Moreover, the true Echinaster is represented by only two species: E. tenuispinus Verrill of La Paz and E. cribrella Lütken of Chile. Indeed, Verrill lists in the fauna of Panama E. aculeatus Gray, but I have found no proof that this species really comes from this region. Other than Echinaster we find an Acanthaster (A. Ellisii Gray) at La Paz and a Mithrodia (M. Bradleyi Verrill) at Panama. It is curious to see Acanthaster reappear at the Strait of Magellan (A. solaris Ellis) while the cribrellids appear at the Cape of Good Hope (C. ornata E.P.) and at Campbell Island where Filhol reported a pretty species, perhaps identical to that of the Cape. Müller and Troschel have likewise described a Solaster from the south-west of Australia, S. decanus. It seems thus that there has reappeared in the southern hemisphere some of the types of the corresponding regions of the boreal hemisphere.

The preceding justifies and makes specific what we said at the beginning of this paragraph. Most seas have one to three species of Echinasteridæ. This family thus does not seem to adopt, like the preceding, some zones more than others. But the genera, on the other hand, are more restricted, as we will specify later.

We do not know the provenance of three species of Echinaster: E. crassus M. T., E. deplanatus Grube, and E. lacunosus Grube.

\section{FAMILLY LINCKIADÆ}

More numerous than the preceding, to which it is related by Mithrodia, this family has seven genera: Ophidiaster, Lepidaster, Linckia, Scytaster, Fromia, Metrodira, and Ferdina. It has a distribution completely different from that we just studied and appears to reach its maximum development in the warm regions. In our seas of Europe, the Mediterranean is the only one in which the Linckiadæ is found. This family is represented there by two species:

Ophidiaster ophidianus Lamk. attenuatus Gray 
The latter is found only in the Mediterranean, but $O$. ophidianus has been collected at Madeira and the Canary Islands by Webb and Berthelot and at the Cape Verde Islands by Bouvier. It also belongs to the warm regions of the Atlantic. In each of the regions that we indicated. It is found associated with other species: Scytaster canariensis d'Orb. at the Canaries, Linckia Bouvieri E. P. and L. Guildingii Gray at Cape Verde.

Without going much higher to the north, the species of the American coast are more numerous. In the Caribbean Sea and Gulf of Mexico are found:

$\begin{array}{ll}\text { Ophidiaster } & \text { Guildingii Gray } \\ \text { Linckia } & \text { Guildingii Gray } \\ \text { Opihidiaster } & \text { Floridae E. P }\end{array}$

The latter is further to the north. Further to the south are cited only O. pyramidatus Gray of Caracas. It is evident that we are not in a special region because the Atlantic and its dependencies, including the Mediterranean, have in all a total of eight species of the approximately fifty six in the family.

On the west coast of the Americas, the species are still not numerous although distributed over very vast expanse. There are six from California to the Juan Fernandez Islands. These are:

$\begin{array}{ll}\text { Linckia } & \text { diplax }^{1} \text { M. T. (California) } \\ ---- & \text { unifascialis Gray (Panama) } \\ \text { Lepidaster } & \text { teres Verrill (Panama) } \\ \text { Ferdina } & \text { Cumingii Gray (Colombia) } \\ \text { Ophidiaster } & \text { fuscus Gray (Migupou) } \\ ---- & \text { Agassizii E. P. (Juan Fernandez) }\end{array}$

However, we find no more than two species in the same location. In the other parts of the Pacific, to the contrary, notably in the Indian Ocean and into the Red Sea, things change. The Red Sea alone has the following species:

$\begin{array}{ll}\text { Ophidiaster } & \text { Hemprichii M. T. } \\ \text { Linckia } & \text { Linckia multifora Lamk. } \\ ---- & \text { Ehrenbergii M. T. } \\ ---- & \text { erythrea Gray } \\ ---- & \text { milleporellal Lamarck } \\ \text { Scytaster } & \text { Egyptiacus Gray }\end{array}$

Nearly all the genera of the family are found from the first representing:

At Zanzibar and in the Strait of Mozambique are the curious

$\begin{array}{ll}\text { Leiaster } & \text { glaber Peters } \\ ---- & \text { coriaceus Gray }\end{array}$

\footnotetext{
${ }^{1}$ Linckia læviuscula Stimpson is a Cribelle according to Verrill.
} 
associated with Linckia diplax M. T., L. miliaris Lamk. L. multifora Lam. and Ehrenbergii M. T. that we have already encountered in the Red Sea and Scytaster variolatus Linck that we will find associated with all the species from the Indian Ocean.

Reunion Island and Mauritius are still richer. Around these islands are:

$\begin{array}{cl}\text { Leiaster } & \text { Leachii Gray } \\ \text { Ophidiaster } & \text { cylindricus Lamk. } \\ ---- & \text { purpureus } \text { E. P. } \\ \text { Linckia } & \text { marmorata Michelin } \\ ---- & \text { miliaris Linck } \\ ---- & \text { diplax M. T. } \\ ---- & \text { multifora } \text { Lamk. } \\ \text { Scytaster } & \text { variolatus Linck } \\ ---- & \text { Nova Caledoniae } \text { E. P. } \\ ---- & \text { Egyptiacus Gray } \\ \text { Fromia } & \text { milleporella Lamarck } \\ ---- & \text { pistoria } \mathrm{M} . \mathrm{T} . \\ \text { Ferdina } & \text { flasvescens Gray }\end{array}$

There is thus a total of thirteen species and this number is perhaps only a minimum. 1866:

In the Indian archipelago, more species are found. Here is the list given by von Martens in

$\begin{array}{ll}\text { Linckia } & \text { miliaris Linck } \\ ---- & \text { multifora Lam. } \\ ---- & \text { pauciforis } \text { v. M. } \\ \text {--- } & \text { Rosennbergi v. M. } \\ \text { Ophidiaster } & \text { pustulatus } \mathrm{v} . \mathrm{M} . \\ \text { Scytaster } & \text { tuberculatus v. M } \\ \text { Fromia } . & \text { monilis Val. } \\ \text { Leiaster } & \text { speciosus } \mathrm{v} . \mathrm{M} .\end{array}$

to which it is necessary to add:

$\begin{array}{ll}\text { Ophidiaster } & \text { cribrarius Ltk. } \\ --- & \text { Germani E. P. (New Caledonia) } \\ \text { Linckia } & \text { pacifica Gray } \\ ----- & \text { Agyptiacus Gray } \\ ---- & \text { gomophia } \text { E. P. (New Caledonia) } \\ ---- & \text { Kuhlii } \text { M. T. (Java) } \\ ---- & \text { obtusus } \text { E. P. (Philippines) } \\ ---- & \text { semiregularis M. T. (Java) } \\ ---- & \text { Nova Caledoniae E. P. } \\ \text { Fromia } & \text { Galathea Ltk. (Nicobar) } \\ \text { Metrodira } & \text { indica } \text { E. P. } \\ & \text { subulata Lam. }\end{array}$


It is difficult to see at present in an absolute fashion if these twenty species are distinct to the coasts of certain islands or extend to nearly all the archipelago. But considering the vast extent in which they are met in several of them, there is a presumption restriction is the exception. We will give, moreover, further on the exact location where most have been found.

In going up the coasts of China and Japan, the species become rare. We have to cite only:

$\begin{array}{ll}\text { Scyaster } & \text { semiseriatus v.M. } \\ \text { Metrodira } & \text { subtilis } \text { Ltk. }\end{array}$

from China and

$$
\text { Fromia Japonica E. P. }
$$

from Japan.

We do not know the provenance of the following species, doubtful for the most part:

$\begin{array}{ll}\text { Ophidiaster } & \text { bicolor Lam. } \\ ---- & \text { arenatus Lam. } \\ \text { Linckia } & \text { intermedia Gray } \\ ----- & \text { Francisca } \text { Nardo } \\ \text { Scytaster } & \text { cancellatus Grube }\end{array}$

These unknowns change nothing to the result. It is quite certain that no other region of the globe has such a great variety of species of Linckiadae than the Indian Ocean.

\section{FAMILY GONIASTERID尾}

The family Goniasteridæ is the most numerous of those we have considered up to here. It is also that which contains the largest number of variable types. We can add that it is one of the most difficult to study well because of the large number of species that have been based on basically unimportant variations of described types, variations that often come from the size of the individuals. We are far from agreeing on the boundaries of the genera that make up this family. We accept the following fifteen:

Nectria Gray

Pentagonaster Linck

Goniodiscus M. T., restricted

Nidorellia Gray

Choriaster Ltk.

Asterodiscus Gray

Culcita Agass.

Goniaster, Agan. S.

Hippasteria Gray

Anthenea Gray

Porania Gray

Asteropsis M. T. 
Dermasterias E. P.

Gymnasteria Gray

We must remark that the names Goniodiscus and Goniaster have here a sense much more restricted than given by the authors who first employed them. On the other hand, the genus Pentagonaster can contain some subdivisions that have been considered as genera by Müller and Troschel, Gray, and others such as Astrogonium, Stellaster, Hosea, Tosia,, Calliaster, Calliderma or Dorigona, etc.

In a general fashion, one can say that the geographical distribution of the Goniasteridæ is superimposed almost exactly on that of the Linckiadoe to which they are related in a very manifest fashion by Fromia and Nectria. However, the area of distribution of Goniasterida is greater, because they are found up to the cold regions of the Atlantic.

If we accept the authors' reports, seven species inhabit the northern Atlantic and the North Sea:

$\begin{array}{cl}\text { Hippasteria } & \text { plana } \text { Linck } \\ \text {--- } & \text { abbensis Forbes } \\ \text { Pentagonaster } & \text { granularis Retzius } \\ ---- & \text { aculeatus Barrett } \\ ---- & \text { borealis Barrett } \\ ---- & \text { hispidus Sars } \\ \text { Porania } & \text { pulvilllus O.-F. Müller }\end{array}$

Of these seven species, the second appears to me only an unimportant variety of H. plana. I have not been able to see the types of Barrett, but they appear very close to $P$. granularis. I cannot confirm their identification. In any case, that makes a maximum of six species in the Atlantic. Up to now, none of them have been reported from Channel, nor on any point on the oceanic coasts of France. They are not found in the Mediterranean where they are replaced by two new species:

\section{Pentagonaster placenta M. T. \\ acutus Heller}

Müller and Troschel also reported a Pentaceros carinatus from the Adriatic. But the later investigations of Heller, de Lorenz, and von Marenzeller did not find this interesting asteroid. To the contrary, I have found in the collection of the British Museulm a very beautiful Pentagonaster, P. mirabilis E. P., which comes from Scala Nova in the Gulf of Smyrna. The Mediterranean contains thus at least three species of Pentagonaster. It is less certain that it includes Pentaceros. This genus appears to have a lower latitude in the Atlantic. Pentaceros dorsatus (Lin.) has been collected by Bouvier at the Cape Verde islands and another species, Pentaceros reticulatus, is abundant in the Antilles and on the coasts of Brazil. There is also at the same locality, the Cape Verde islands, a species of Pentagonaster, P. semilunatus Linck.

The Red Sea is a little richer. It has two Pentaceros:

$\begin{array}{ll}\text { Pentaceros } & \text { mammillaltus Audouin } \\ --- & \text { tuberculatus M. T. }\end{array}$


a culcitid

Culcita coriacea M. T.

a gymnasterid

\section{Gymnasteria carinifera Lamarck}

only four species but three genera. A new culcitid appears at the latitude of Zanzibar. It is Culcita Schmideliana Retzius. Another is added at Mauritius, C. Nova Guinea. But at the same time three culcitids occur in this region:

$\begin{array}{ll}\text { Pentaceros } & \text { hiulcus Linck } \\ \text {--- } & \text { turritus Linck } \\ ---- & \text { muricatus Linck } \\ \text { Goniaster } & \text { obtusangulus Lamarck }\end{array}$

The latter is close to Pentaceros. It is necessary to add to this list Gymnasteria carinifera Lamk. that occurs in the Red Sea. This increases to eight the number of Goniasteridæ from the Mascarene Islands, and probably from the east coast of Africa. It should be noted that the genus Pentagonaster, so typical and so numerous, is not up to now, represented in this fauna. It is only further to the east that we find it in a region whose climate is more temperate. However, according to a label in the museum of Cambridge (Massachusetts), Pentagonaster semilunatus Linck, has been found at Zanzibar and P. (Astrogonium) tuberculatus from Port Natal.

The Seychelles has a fauna very analogous to that of the Mascarenes. We find there however, a new form: Anthenea articulata Val. (s. r.) and perhaps also Goniodiscus capella M. T. But it is around the Australian continent that the family Goniasteridæ acquires its maximum development. Here are the forms represented there:

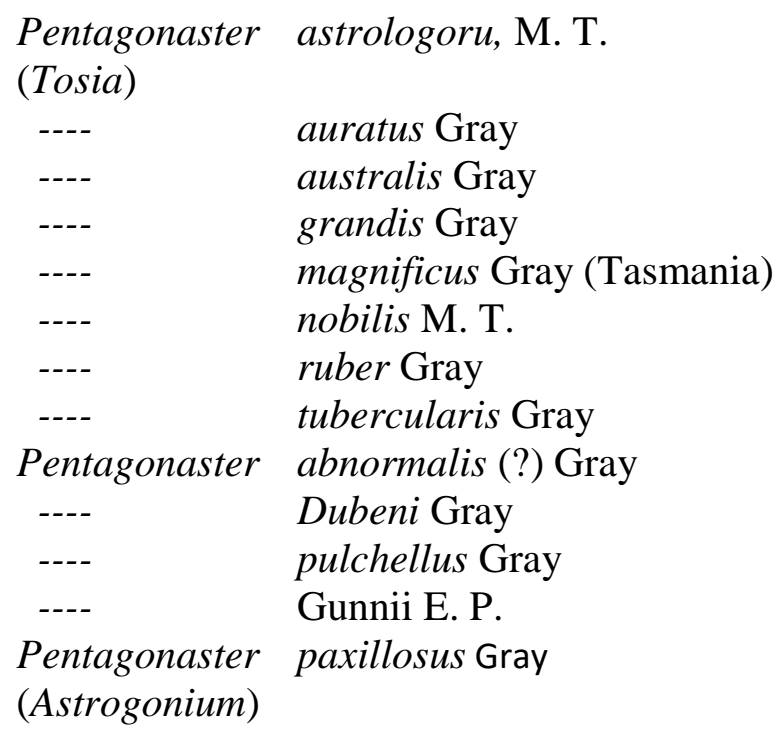




$\begin{array}{ll}\begin{array}{l}\text { Pentagonaster } \\ \text { (Stellaster) }\end{array} & \text { Incei Gray } \\ \text { Anthenea } & \text { acuta } \text { E. P. } \\ \text { Culcita } & \text { Nova Guinea M. T. } \\ \text { Pentaceros } & \text { granulosus Gray } \\ \text { Pentaceros } & \text { australis Lütken } \\ ---- & \text { nodulosus Gray } \\ ---- & \text { Franklinii Gray } \\ ---- & \text { gracilis Lütken } \\ ---- & \text { valvulatus E. P. }\end{array}$

It is a total of twenty four species to which it will be necessary, without doubt, to add still some of those living in the Malaysian archipelago and the nearby regions of New Guinea.

New Zealand has a fauna that can be considered as a reduction of the preceding. We still find there Pentagonaster pulchellus Gray associated with other forms of Pentagonaster:

$\begin{array}{ll}\text { Pentagonaster (Tosia) } & \text { magnificus M. T. } \\ \text { Pentagonaster } & \text { dilatatus E. P. } \\ \text { (Astrogonium) } & \text { miliaris Gray }\end{array}$

But Pentaceros and Anthenea have disappeared and, to find them again, it is necessary to leave Australia to approach, to the contrary, the equator. The Indian archipelago is not richer, moreover, than the Australian coast. Here is the list of species that have been reported there:

\begin{tabular}{|c|c|}
\hline Pentagonaster & $\begin{array}{l}\text { clavatus v. Mortens (Flores, Lesser Sunda } \\
\text { Islands) }\end{array}$ \\
\hline---- & semilunatus Linck (Celebes) \\
\hline $\begin{array}{l}\text { Pentagonaster } \\
\text { (Astrogonium) }\end{array}$ & incequalis Gray (Amboine, New Guinea) \\
\hline--- & spinulosus Gray (Philippines) \\
\hline $\begin{array}{l}\text { Pentagonaster } \\
\text { (Dorigona) }\end{array}$ & longimanus Möbius (Sumatra) \\
\hline $\begin{array}{l}\text { Pentagonaster } \\
\text { (Stellaster) }\end{array}$ & equestris Retzius (Sumatra) \\
\hline ---- & gracilis Gray (Moluccas) (Philippines) \\
\hline $\begin{array}{l}\text { Pentagonaster } \\
\text { (Stellaster) }\end{array}$ & Belcheri Gray (Amboine) \\
\hline Goniodiscus & cuspidatus Lam. \\
\hline ---- & pleyadella Lam (Moluccas) \\
\hline---- & Seba M. T. (Amboine) \\
\hline Pentaceros & obtusatus Bory de Saint-Vincent \\
\hline Culcita & grex M. T. \\
\hline---- & pentagularis Gray \\
\hline ----- & $\begin{array}{l}\text { Novæ Guineæ M. T. } \\
\text { carinifera Lam. }\end{array}$ \\
\hline
\end{tabular}


This makes sixteen species. But is probable that it is necessary to add to this list some species from the Mascarene Islands whose analogues are found at New Caledonia, Pentaceros turritus Linck, for example.

What is most striking about this fauna is the predominance of forms with long arms like Pentagonaster and Goniodiscus over the nearly pentagonal forms that are, to the contrary, more numerous in Australia. Pentaceros are also less numerous but there is, I think, a gap to fill. The Indian Ocean proper has only seven of them.

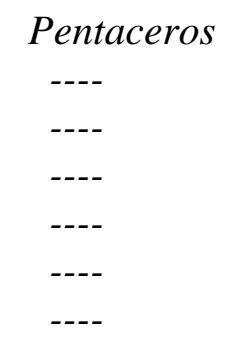

\author{
superbus Möbius \\ Westermanni Lütken (Bengale) \\ Hedemanni Lütken (Billeton) \\ Reinhardti Lütken (Nicobar) \\ affinis M. T. \\ regulus Val. (Pondichery) \\ verrucosus $\mathrm{M}$. T.
}

We must recognize in the list three species that have very uncertain information. India or the Indian Ocean does not guarantee their provenance. It is curious that no Pentagonaster has yet been reported in this poorly known region.

On the coasts of China and Japan, the fauna keeps the character that we have seen in the Indian archipelago but with some modifications in the species and a notable reduction in their number.

$\begin{array}{ll}\text { Pentagonaster } & \text { semilunatus Linck } \\ \text { Pentagonaster (Calliaster) } & \text { Childreni Gray } \\ \text { Pentagonaster (Calliderma) } & \text { Emma Gray } \\ \text { Pentagonaster (Stellaster) } & \text { equestris Retziuus } \\ \text {---- } & \text { tuberculosus v. Martens } \\ \text { Pentagonaster (Dorigona) } 1 & \text { Mülleri } \text { v. Martens } \\ \text { Goniodiscus } & \text { granuliferus Gray } \\ ---- & \text { capella M. T. } \\ \text { Pentaceros } & \text { orientalis M. T. } \\ ---- & \text { Chinensis M. T. } \\ \text { Asterodiscus } & \text { elegans Gray } \\ \text { Anthenea } & \text { pentagonula Lam. (Hong Kong) }\end{array}$

These twelve forms are all very remarkable. Among them, Asterodiscus replaces culcitids of which it can be considered a variety. It is unfortunate that for none of them do we have a precise indication of locality.

If we refer to the east and to the south, towards New Caledonia, the Fiji Islands, etc., we continue to find Pentaceros. New Caledonia has the following:

$\begin{array}{cl}\text { Pentaceros } & \text { turritus Linck } \\ ---- & \text { alveolatus E. P. } \\ ---- & \text { Caledonicus E. P. }\end{array}$


But we still have not received any Pentagonaster nor any culcitid. However, this can only be accidental, because Filhol has reported Culcita pentagularis Gray from the Fiji Islands and the Torres Strait and culcitids are found also at Hawaii (Culcita arenosa Val.) and Saint Paul Island (C. Veneris E. P.). Fiji is again notable by the beautiful Choriaster granulatus Ltk, near Pentaceros. We add finally Gymnasteria carinifera Lam. that we have so often encountered living in these islands, Hawaii and very probably also in New Caledonia.

There remains to examine the distribution of the Goniasteridæ on the west coast of the Americas. There, the species are not numerous. We are evidently far from the center of distribution or, more exactly, the principal accumulation.

On the California coast are found:

Mediaster aequalis Stimpson

Amphiaster insignis Verrill (La Paz, Mexico)

Nidorellia Michelini E. P. (Mazatlan, Mexico)

further down

Nidorellia armata Gray (Acapulco, Panama)

It is associated in this last locality with Gymnasteria carinifera Lam. and with related species such as our Dermasterias inermis (Asteropsis imbricata Grube) and Asteropsis vernicina Lam.

We find again an interesting species of Gymnasteria (G. valvulata E. P.) from the Galapagos Islands and on the coast of Ecuador the curious Nidorellia horrida (Gray) that replaces the two more northern species.

It is also in this region that occur the only two Pentaceros reported on this coast, $P$. Cumingii Gray and occidentalis Verrill, which perhaps are identical.

For the coast that follows, we lack information. But at Chile reappear species that recall a little the physiognomy of Australian species:

\author{
Pentagonaster Fonki Philippi \\ Pentagonaster (Astrogonium) verrucosus Philippi \\ ---- singularis M. T. \\ Goniodiscus penicillatus Philippi
}

$P$. singulatus goes much further down. It is found in the Strait of Magellan and along with a poranid very near to $P$. puvillus that we propose to name $P$. patagonica.

Of the 113 species that make up this family at the present, only nine still do not have a well-established habitat. These are the following:

Nectria ocellifera Lam.

Pentagonaster (Tosia) ornatus M. T.

Pentagonaster (Tosia) Lamarckii M. F.

Pentagonaster (Tosia) regularis Linck

Pentagonaster (Astrogonium) mammillatus M. T.

Pentagonaster (Astrogonium) punctatus Lam. 


\section{Anthenea flavescens Gray \\ Anthenea scaber Möbius}

The first of these species comes from Australian seas (expeditions of Péron and Lesueur), probably from the Australian coast itself. Pentagonaster regularis, mammillatus and punctatus are doubtful species whose type cannot be found and it perhaps it is necessary to delete them as duplicates. There are three species for which we do not have geographical information.

We can thus consider as well known the geographical distribution of the Goniasteridæ. Their center is found evidently on the coast of Australia and in the archipelagos of Malaysia and Melanesia. They decrease already on the coast of China and also towards the east. There are only a few species on the Pacific coast of America. Our European seas and the Atlantic all together have only about ten species. I do not give an exact number because some of these species are still doubtful. There remains more than eighty species for the Indian Ocean, China, Australia and the archipelagos of Oceania.

\section{FAMILY ASTERINIDÆ}

The Asterinidæ is a small family that has only the five genera Disasterina, Palmipes, Asterina, Patiria and Ganeria and 31 species. A glance at the map of their geographic distribution shows that these starfish inhabit only warm and temperate seas. They are not found, according to Lütken, on the coasts of Norway. But Asterina gibbosa is found on the coasts of England. It is abundant in the Channel, on the entire European coast of the Atlantic and in the Mediterranean. Throughout this region it is associated with Palmipes membranaceus Linck that lives only, in general, in deep water, although de Lacaze-Deuthiers found it on the beach of Brest at low tide, in the conditions where one ordinarily finds Asterina ciliata in the Mediterranean. So our European seas do not have simultaneously two or three Asterinidæ. This is nearly the same thing everywhere. We know two species on the American Atlantic coast: A. minuta Gray and A. stellifer Möbius, both from the Antilles. The latter is found on the coast of Brazil and at Senegal. Moreover, Dr. Lüken has communicated to me a new species from Barbados that he names A. Wesseli. It should be noted that on the coast of the United States, below our latitude, no one has reported Asterina and a single species has been mentioned on the coast of Brazil. On the coast of Patagonia, only Ganeria Falklandica represents the family. But there is already a very marked form of transition towards the Astropectinidæ, to which it is connected by Ctenodiscus. The Chilean coast is richer. The following five species are there:

Asterina Chilensis Lütken
Asterina calcarata Val.
Asterina Gayi E. P.
Asterina pusilla E. P.
Asterina fimbriata E. P.

But only two species have been mentioned at Panama, Asterina modesta Verrill and obtusa Gray. Finally, only one species inhabits the coast of California, A. miniata Brandt and only three species for the long coast that extends from Chile to the Behring Strait! 
We return now to the Atlantic. At Senegal, we can report two species:

Asterina stellifer Möbius

Asterina squamata Val.

Then, nothing until the Cape, where are found:

Asterina exigua Lam.

Asterina coccinea M. T.

Asterina Granifera Gray

Madagascar and Reunion Island have the same fauna as the Red Sea where one can collect:

Asterina cephea Val.

Asterina Wega Val.

Asterina penicillaris Lam.

Asterina Burtonnii Gray

Asterina exigua Lam.

and, they say, Asterina gibbosa Pennant. We must however have reservations on the subject of some of these species. A. burtonnii and A. gibbosa could be only A. cephea. This would reduce to four the number of species from the Red Sea. A. cephea extends throughout the Indian archipelago where it meets A. regularis whose principal station is around Australia up to New Zealand. von Martens reports $A$. coronata from the Mollucas. This makes three species from the Indian archipelago.

Australia shares a little better because on its coast are found:

\author{
Asterina regularis Verrill \\ Asterina Gunii Gray \\ Asterina calcar Lam. \\ Asterina exigua Lam. \\ Patiria crassa Gray (west coast) \\ Nepanthia brevis (Strait of Prince of Wales)
}

In all, six species of which the first four are found at the same place.

The first of these species is found abundantly at New Zealand at the same time as another starfish of the same family, the remarkable Palmipes inflatus, described by Hutton as a Pteraster. It is necessary to add another true Asterina that I have named A. Nova Zealandice.

The Asterinidæ fauna of New Caledonia is reduced to two species. One, A. cephea Val., is in common with the India archipelago, the Mascarenes and the Red Sea. The other is distinct and merits a distinct genus, Disasterina abnormalis, E. P.

From the Hawaiian Islands, we recognize again only one species that is unique to them, $A$. granulosa E. P. Finally, at Japan, is A. pectinifer M. T. and the superb Palmipes rosaceus Lam., which is to two other species, Acanthaster and Solaster, as Heliaster and Pycnopodia are to Echinaster and Asterias. 
Except for the very austral or boreal seas, except for the west coast of North America that appears impoverished, we see that nearly all the seas contain two to six species of Asterinidæ. There is a nearly uniform distribution. We cannot indicate here a well-defined region that we have presented for other families, notably the Linckiadæ and the Gonioasteridæ

\section{FAMILY PTERASERIDÆ}

This family is made up of a small number of species inhabiting deep waters and recalls a little the general aspect of the Asterinidæ for which they seem to substitute in the northern regions of the Atlantic.

At Greenland, Iceland, on the coasts of Norway, England and the United States and up to Spitzberg are found Pteraster militaris M. T. in deep water and P. multipes Sars and P. pulvillus G. O. Sars in deeper water. Still deeper is Hymenaster pellucidus W. Thompson, which is only a true Pteraster. But it is not only in cold water where this genus is found. We owe to A. Agassiz the knowledge of a species that we have named P. caribboeus that has been collected at Casco Bay (state of Maine) and at Sand Key (Florida) at a depth of 125 feet. Pteraster dance Verrill is also found lower on the Brazilian coast.

Finally, two species of large size are sufficiently different from the preceding perhaps to justify creation of a genus. These species that have, to the contrary, between them the greatest similarity, inhabit the Cape ( $P$. Capensis Gray) and Zanzibar, the Philippines and perhaps other locations of the African coast and the Indian archipelago (P. cribrosus v. Martens).

This is all that we know at the present on the distribution of the Pterasteridæ, but it is necessary to remember that these delicate animals, living in deep water, are difficult to collect. It is without doubt that submarine explorations, such as the English and the Americans have taken the initiative, will make known a greater number of species.

\section{FAMILY ASTROPECTINIDÆ}

Here again is a very numerous family that contains 100 very homogeneous species that includes the genera Chaetaster, Luidia, Archaster, Astropecten and Ctenodiscus. Two (Archaster and Astropecten), including alone more than three quarters of the species of the genus, are scarcely distinct from each other. Chaetaster has only three species, Ctenodiscus has two. The Astropectinidæ are found in all the seas, the coldest as well as the warmest. It is true that Ctenodiscus crispatus alone faces the icy seas of Spitzberg and Greenland, although it is found down to the English coasts. But among the Finnish species, we can report two other starfish of the same family, Archaster arcticus Sars and Parelii Düben and Koren, of which the latter is associated on the coasts of Norway with Astropecten irregularis Pennant, Archaster Christi Düben and Koren and tenuispina Düben and Koren and Luidia Sarsii D. amd K., all living in deep water. We have reported other species in the North Sea under the names of Astropecten squamatus M. T., A. acicularis Norman, A. echinulatus M. and A. Lutkeknii Barrett. But A. echinulatus, according to Sars, is identical to A. irregularis Pennant. The other species do not appear sufficiently distinguished. More recently, Wyville Thompso has reported two other species from deep water, Archaster bifrons $\mathrm{W}$. T. and A. vexillifer $\mathrm{W}$. T. It is clear from all this that there are a very large number of Astropectinidæ in the cold deep water of the Atlantic and that one species even extends into polar waters like some Asteriadæ. Luidia ciliaris begins, according to Norman, to be found 
on the English coast along with L. Sarsii D. K. These two species have been confused by Forbes with the name L. fragillissima.

Astropectinidæ are rare in the Channel or are found only at great depths. I have seen no specimen from these waters in the collection of the British Museum or that of the Jardin des Plantes. I have never seen them in the fishing nets brought back to Roscoff although they contain Asterias glacialis, Echinaster sepositus Cribrellal oculata, Solaster papossus and Palmipes membranaceus in abundance. However, at least three species are found on the French Atlantic coast: Astropecten aurantiacus and A. serratus Val. and Luidia ciliaris collected by Fischer at Arcachon.

The species increase in the Mediterranean:

Chaetaster longipes Retzius
Luidia ciliaris Philippi
Archaster subinermis Philippi
Astropecten aurantiacus Linné
Astropecten Johnstonni Delle Chiaje
Astropecten hispinosus Otto
Astropecten pentacanthus Philippi
Astropecten spinulosus Philippi
Astropecten aster Philippi
Astropecten serratus Valenciennes

These eleven species can perhaps be reduced to a smaller number. However, most of them seem very distinct although we have been able to see only a few specimens of some of them. Thus von Marenzeller affirms the identity of A. spinulosus Philippi with A. Johnstoni Delle Chiaje. More recently, Dr. Lüken has described with extreme care the specimens in the museum of Paris, studied by Troschel, that have always had the name A. platyacanthus. Dr. Lüken, to the contrary, considers these two species have no relation to each other. Lacking means of verification, we ourselves are quick to accept his very clear opinion, but we do still do not know which is the true $A$. platyacanthus.

Returning to the Atlantic, we find A. aurantiacus Linné up to the Canary Islands. Astropecten Schoenleinlii M. T. and Luidia senegalensis M. T. are found on the coast of Africa. The latter also inhabits the coast of Brazil and the Antilles. But it is the sole asteride of this family common to the two coasts.

On the east coast of the Americas, we can report:

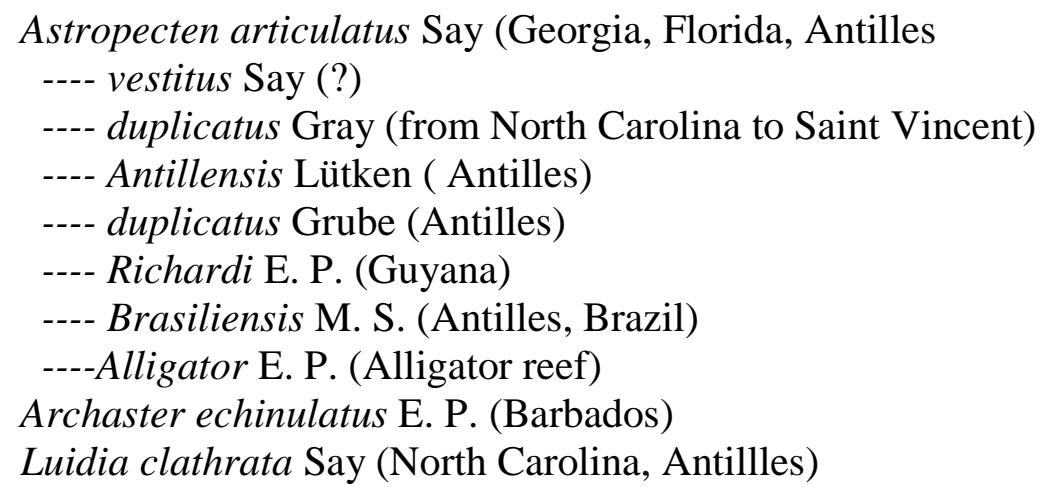


---- alternata Say (Florida, Antilles)

---- Senegalensis M. T. (Antilles, Brazil)

----variegata E. P. (mouth of the Mississippi, Strait of Florida)

---elegans E. P.

Chataster nodosus (Antilles)

Nine species are recorded from the Antilles. Verrill likewise cited nine, but it is necessary to note that several of the names listed are duplicates. Such are A. articulatus Say and A. dubius Gray, A. variabilis Ltk. Astropecten Valenciennesi M. T. is identical to A. duplicatus. On the other hand, he did not know of the existence of Chataster nodosus, collected by Duchassaing at Guadeloupe. Finally, it is quite possible that the four other species that live at very great depths will be found elsewhere. We can thus consider the Caribbean as a kind of center that unites all the American Astropectinidæ, whose numbers decrease with distance from it. I will add that Müller and Troschel have described, as coming from the Antilles, Chaetaster Troscheli named by Valenciennes in the collection of the museum of Paris whose type cannot be found. It does not seem that this species can be confused with $C$. nodosus whose arms are nearly two times longer.

The species of the opposite side of the Americas are nearly as numerous but completely different. We can count there one Chataster, three Luidia and six Astropecten.

Chataster Californicus Grube

Luidia Californica Ltk.. m. s. (California)

---- tessellata Ltk. (Colombia)

---- Bellona Ltk. (Guyaquil)

Astropecten erinaceus Ltk. (Panama and Nicaragua)

---- alatus E. P. (??)

--- latiradiatus Gray (Tehuantepec)

---- spatuliger E. P. (Nicaragua)

---- fragilis Verrill (Panama)

---- Peruvianus

It is again the equatorial zone that dominates because of ten species it has at least six.

In continuing our route to the west, we find Japan nearly as rich with:

Luidia maculata M. T.

Archaster hesperus M. T.

--- Japonicus M. T.

---- scoparius Val.

---- armatus Gray

---- numbrinus Grube

---- velitaris v. Martens

---- Chinensis Grube

Astropecen armatus, that we recognize here for the first time, will now be associated with all the species of the Indian Ocean and will be found to the base of the Red Sea.

A remarkable species, $A$, Samoensis, is found at the Fiji Islands. On the eastern coasts of Australia are A. vappa (A. armatus?) M. T., A. Pressii M. T. and A. triseriatus M. T. Finally, 
another species, A. Edwardsi Verrill, inhabits the Auckland Islands and New Zealand. At the Sonde Islands are:

\author{
Astropecten armatus Gray \\ --- Javanicus M. T. \\ ---- longispinus M. T. \\ ---- scoparius Val. \\ Archaster angulatus M. T. \\ ---- typicus $\mathrm{M}$. T. \\ Luidia maculata M T. \\ ---- Hardwickii Gray \\ Choetaster cylindratus Möbius
}

Most of the species are found at the Mascarene Islands where A. Mauritianus Gray is perhaps only a variety of A. scoparius Val. but cannot be confused with Archaster angulatus M. T. as von Martens would like. We add finally that the Museum has received from Bailleu, consul at the Hawaiian Islands, a species that appears new and that we name Astropecten Baillaei.

From Poulo Condor Islands, located opposite the mouth of the Mekong, the grand river of Cambodia, Dr. Harmand sent us another interesting species that we will name A. Harmandi. Finally, in the beautiful collection that we owe to Alexander Agassiz, we find an equally new species from Calcutta, A. Indicus E. P. It is necessary to cite in the same waters (Nicobar Islands, Astropecten euryacanthus Lütken.

The number of species of the tropical region of the Indian Ocean is thus very considerable. It is approximately fifteen. To what degree are these last species associated into the same fauna? It is still impossible to say. Most have been described only from species collected at a single locality. No study has been made to establish the extent of their distribution or their habitat. What is well known, however, is that one, A. armatus Gray, is found in nearly the entire region.

Whatever it is, the information that we have establishes that the warm seas are the preferred habitat of the Astropectinidæ. They are less numerous in temperate seas. But some of them have advanced to just below the polar seas.

We have no indication about the place of origin of the following sixteen species:

Choetaster Hermannii M. T.

Luidia debilis Grube

---- foliolata Grube

Astropecten diplacanthus Grube

----paleatus Grube

---- Olfersii Grube

---- Buschii Philippi

---- calcitrapa Lamarck

---- fimbriatus Linck

---- regularis Linck

---- mesodiscus Linck

---- gracilis Gray

---- granulatus Müller and Troschel

---- hispidus Müller and Troschel 
---- marginatus Müller and Troschel

---- Tiedemanni Müller and Troschel

\section{FAMILY BRISINGIDÆ}

This family of asteroids that is considered, without good cause perhaps ${ }^{2}$, as making a transition to the ophiuroids contains only the single genus Brisinga Absjörnsen. This genus itself has only two species from deep regions of the Atlantic. Brisinga endecacnemos Absjörn., has been dredged from 100 to 200 fathoms depth in the waters of the Bergen archipelago and in those of the Lofoden Islands. It is also in these regions (Skraaven) that Michael Sars collected Brisinga coronata that the dredges of Wyville Thomson had collected from other localities of the Atlantic between Scotland and the Faroe Islands (500 feet) and near the coasts of Ireland (800 feet). Brissinga endecacnemos has been collected at 1,000 feet by the Porcupine off the coast of Portugal. It extends as high to the north and more to the south than B. coronata.

It would be bold to state that the Brisingidæ inhabit only rare localities of the Atlantic where the small number of specimens found in museums were collected, because we are still very far from having esplored methodically even our European seas.

We will end the study of the mode of distribution of the families of the class of starfish. All have a very vast area of distribution. But it has been possible to assign for most of them the limits that they do not pass and to show that there exist regions where they seem to develop easily, where the number of their species reaches a maximum, the number decreasing more or less quickly according to the distances in any direction from these areas. It is appropriate now to pose the question more narrowly and to begin for the genera the study that we have made for the families.

\section{GEOGRAPHICAL DISTRIBUTION OF GENERA}

The mode of distribution of the groups designated as families we just considered are near those that Müller and Troschel 35 years ago called genera. Our Asteriadæ corresponds to their genus Asteracanthion except for the Pedicellaster and Labidiaster that were yet unknown.

Our Echinasteridæ corresponds to their genera Solaster and Echinaster. Only we had to transfer Asterias striata Lamarck, which the Germans believe to be an Asteracanthion, into this family. And another species, Asterias clavigera, of the famous French zoologist that the same authors had made an Ophidiaster.

The family Linckiadæ that we have adopted corresponds exactly to the genera Ophidiaster and Scytaster of the System der Asteriden. The same is true for the Gonioasteridæ that corresponds to the genera Astrogonium, Goniodiscus, Culcita and Oreaster in the same work. Finally, the family Asterinidæ is only the genus Astericus, less Pteraster and Astropectinidæ are only the genera Astropecten and Luidia, to which we add Chataster.

Thus each family that we have discussed previously can be divided into a very small number of the former genera. The maximum number of divisions is four, in the Goniasteridæ. We must note that in the Linckiadæ, the character used by Müller and Troschel to distinguish

\footnotetext{
${ }^{2}$ Since these lines were written, I must recognize, thanks to the kindness of Lacaze-Duthiers, a substantial memoire by G.-O. Sars on the brisingids. It refers to the research of this scholar that these interesting ecohinoderms are clearly true asteroids near Asterias. Their crossed pedicellariae are identical to those of all Asteriadæ. We do not hesitate to suppress the family Brisingidæ and place the genus Brisinga in the family Asteriadæ next to Pedicellaster and especially Labidiaster.
} 
Ophidiastser from Scytaster does not hold in view of new observations and several authors have proposed to combine the two genera. It is the same for the character they used to distinguish Astrogonium from Goniodiscus that we propose again to unite under the generic name of Goniaster. Thus, according to von Martens, for example, the genera of Müller and Troschel can verry well be reduced in the following fashion, using only those species recognized by these scholars.

\author{
Asteriadæ: Asterias (Asteracanthion) M. T. \\ Echinasteridæ: Echinaster, Solaster \\ Linckiadæ: Linckia \\ Goniasteridæ: Goniastser, Oreaster, Culcita. Gymasterias \\ (Asteropsis) M. T. \\ Asterinidae: Asterina (Asteriscus) M. T. \\ Pterasteridæ: Pteraster \\ Astropectinidæ: Chætaster, Luidia, Astropecten
}

It is necessary to add the Brisingidae for Brisinga. Thus eight families and fourteen genera: five families each have only one genus and consequently do not concern us. Three families have two, another three, and the last four genera. We would have, even for them, very little to add to that we have already said.

Although this view has the support of some eminent naturalists, that Dr. Lütken notably is very close to accepting the genus Goniaster as he understood von Martens, we believe it necessary to proceed otherwise. There is no practical criterion that allows distinguishing a good genus from a bad one. Each author, when he wants to defend his genera, must give the principles that he used for their defining them. On the other hand, when it is a question of the general way to any category of divisions used in classification, it is necessary to say how they have been used. To systematically investigate the laws of the distribution of genera without saying what the word genus means would be nonsense. Here is how the genera I have accepted differ from those of Müller and Troschel and even more from those of von Martens.

When we consider the series of species that make up the genera of these authors it is easy to state the two following facts:

1. Some species in these genera are separated clearly from their congeners, either by an ensemble of a certain number of characters or by very apparent characters.

2. The remaining species, when those of the preceding category are eliminated, although more similar to each other, can be placed into less extended groups when certain characters are used, less apparent without doubt that those on which the large genera are based, but often very precise and evidently related to the organization of the animal. Such are the characters of the skeleton and its relation with the dermis in which it developed.

It seems to me that there is an advantage for the homogeneity of the genera to remove aberrant species in giving them a specific generic name.

On the other hand, it is equally advantageous to indicate all the modifications of a structure that individuals of the group can show. If the exterior ornamentation or even the usual relative sizes of the parts are used to define to define the species, the modifications, either in form or arrangement, have a dfferent importance. We thus are inclined to define our genera according to the form and arrangement of the skeletal pieces, rejecting, to the contrary, all previous genera that were based only on the presence or absence and the arrangement of the dermal granulations, or on 
the number of rows of ambulacral spines as are several of Gray's genera. We have not, moreover, had to introduce many new names, Gray having pushed to the last limits the fragmentation of families. We do not pretend, on the other hand, that our divisions have in any way a definitive character. Our knowledge regarding the descriptions of the skeleton and its pieces, our knowledge regarding the comparative anatomy of asteroids are still too incomplete that, in the future, very extensive modifications will be made to our present classification. But we just indicated the principles on which they will be based. We know how we have understood the genera and how the study that we are going to make on their geographical distribution will look. We hope at least to confirm the value of those that we have adopted and that, we repeat, very few are new.

\section{FAMILY ASTERIADÆ}

\section{GENUS ASTERIAS}

This genus corresponds completely to the genus Asteracanthion Müller and Troschel. We believe it is necessary to separate Stichaster, formerly distinguished by Müller and Troschel themselves and whose compact skeleton, formed of pieces arranged in longitudinal series, is truly particular, as well as Heliaster, whose large disc, numerous short arms and pedicelllariae are truly characteristic. We have already said that Asteracanthion striatus must be placed in the family Echinasteridæ as the genus Valvaster. On the other hand, we have seen no good reason to include the genera Margaraster and Uniophora of Gray, based only on the form of skeletal spines. Likewise, the genera Leptasterias and Coscinasterias of Verrill have modifications too small from the type that we believe it is necessary to keep them. The genus Asterias thus understood contains nearly all the Asteriadæ. We thus can apply to it all we have said of the family. It is nearly completely absent from tropical regions, notably in the Indian Archipelago and likewise on the west coast of South America. Temperate zones make up the principal areas of distribution. It goes north to Spitzberg and its species are abundant on the two coasts of North America, the coast of Chile and southern Australia. European seas, with only four confirmed species, are infinitely less well endowed. We will not repeat here the list that has been given before to better indicate that Asterias is nearly the entire family, disregarding the aberrant forms.

\section{GENUS HELIASTER}

The genus Heliaster has a very distinct area of distribution. It is exclusively restricted to the east (sic) coast of the Americas. Its five species, some of which are doubtful, range from the coast of Chile and the Galapagos Islands up to the Gulf of California. All known forms are very close to each other. At first glance, one would take them as unimportant varieties.instead of distinct species.

\section{GENUS PYCNOPODIA}

The genus has only one species with numerous rays and has an extreme reduction of its dorsal skeleton. Pycnopodia helianthoides Brandt sp., inhabits the east (sic) coast of North America, from Sitka Island to Cape Mendocino. The specimens in the Museum are from California.

\section{GENUS STICHASTER}

We include Stephanasterias and Calasterias of Verrill here. Stephanasterias albulus belongs to boreal regions. Stephanasterias roseus is from northern regions of the Atlantic. Stephanasterias 
aurantiacus is from Chile. Stephanus australis is from New Zealand. This is a curious distribution and that calls for new work on the real relations that unite these species.

\section{GENUS CALVASTERIAS}

A single species from the Torres Strait.
C. asterinö̈des E. P.

GENUS ANASTERIAS

A single species of unknown origin,

A. nuda E. P.

GENUS LABIDIASTER

A single species from Patagonia.

L. radiosus Lovén

\section{GENUS PEDICELLASTER}

A single species discovered by Sars from the North Atlantic.

It is not out of context to note here how species with multiple arms are relative numerous on the west coast of the Americas. While in other parts of the world, we can only cite A. muricata and S. australis, both from New Zealand, and A. tenuispina from the Mediterranean and warm regions of the Atlantic that normally have more than five or six arms. We find on the American Pacific coast, going from north to the south, Pycnopodia helianthoïdes (ten to eleven arms), five species of Heliaster (fifteen to forty arms) and with them on the coast of Chile, Aserias gemmifer (eleven arms) and A. gelatinosa (six to eight arms), and finally on the coast of Patagonia, Labidiaster radiosus (31 to $35 \mathrm{arms}$ ). With these species are found moreover many others that have, as usual, five or six arms.

\section{ECHINASTERIDÆ}

If one includes in this family only the two genera Solaster and Echinaster, like von Martens, it would be necessary to consider Echinaster as cosmopolitan. We divide it into the following five genera: Acanthaster, Echinaster, Valvaser, Criibrella and Mithrodia. The geographic distribution of these genera should then become remarkably clear. The family is completed by the genus Solaster, accepted by all auhors.

\section{GENERA SOLASTER AND CRIBELLA}

Between the distribution of these two genera, we note a remarkable coincidence. We find Solaster endeca in all the arctic seas. At Greenland, the Behring Strait, etc. Solaster papposus goes down 
to the Channel — another species inhabits the southwest coast of Australia. Likewise, the cribrellids go north to Greenland and down to the French coast of the Atlantic. Moreover, one species has been found in the southern hemisphere at the Cape of Good Hope and another, perhaps the same, at New Zealand (Filhol).

\section{GENUS ECHINASTER}

Removing the cribrellids, the genus Echinaster occurs exclusively in warm and temperate regions. In our European seas, we find only one species, E. sepositus that long was thought to be restricted to the Mediterranean. But Fisher has found it in the Bay of Biscay. We have found it in the Channel and at Roscoff (Finistere) where it coexists with Cribrella oculaa. The other species, not numerous, inhabit the east coast of Africa and the Indian archipelago. Two species are found on the coast of Panama and four from North Carolina down to and including the Caribbean.

\section{GENUS ACANTHASTER}

Except for the Red Sea, the genus Acanthaster occupies the entire tropical region of the Pacific, to Panama. Outside this region, I have reported another Acanthaster at the Strait of Magellan. But the Labidiaster of Lovén that apparently has a very great resemblance to Acanthaster is also found in this region. One can ask if there is confusion between these two genera. Moreover, an Acanthaster has been reported also from the Galapagos Islands. It is not impossible, consequently, that the genus goes down to the coast of Patagonia. We call for new information.

\section{GENUS VALVASTER}

A single species known by a single specimen from Mauritius, V. striatus (Asterias striata Lam., Asteracanthion striatus Müller and Troschel).

\section{GENUS MITHRODIA}

Disregarding the aberrant station from the Strait of Magellan, Mithrodia seems to be superimposed on Acanthaster, like Cribella on Solaster. We find them in the Red Sea, on the east coast of Africa, at the Mascarenes, at the Philippines, the Hawaiian Islands and, finally, at Panama.

The respective areas of the various genera of Echinasteridæ are thus very clearly circumscribed - we find for the first time in this family two very clear examples of the genera that inhabit the cold or temperate parts of the two hemispheres, austral and boreal, and totally lacking in warm seas of the tropics.

\section{FAMILY LINCKIADIÆ}

From what we have seen, the family Linckiadiæ has a much more restricted area of distribution than the families we have just considered. On the other hand, the genera have approximately the same number of species. It is thus nearly a necessity that their particular areas where they are found overlap considerably. These areas are not, however, completely overlapping as we shall see in the following discussion. 


\section{GENUS OPHIDIASTER}

This is the only genus of the family that is found in European seas. Two species occur in the Mediterranean. One of them, O. ophidianus has been found in the Atlantic at Madeira in the Canary Islands (Webb and Berthelot) and at the Cape Verde Islands (Bouvier). Ophidiaster Floridae E. P. occurs in the Strait of Florida and the Ophidiaster Guildingii Gray) occurs in the Caribbean Sea. These are the only species known for the Atlantic. All the other nineteen species are found in the Red Sea, the Mascarene Islands, the east coast of Africa, the Indian archipelago, China, New Caledonia, and even on the west coast of Africa, but in the warm region only.

It should be noted there is no Ophidiaster on the east coast of South America - on the coast of North America, they are not found above Cape San Lucas and Florida. The only species on the west coast of South America comes from Juan Fernandez Islands.

\section{GENUS LINCKIA}

The area of distribution of Linckia is a little less extensive. It is not found in European seas. They are found in the Atlantic only on the coast of the Cape Verde Islands (two species) and the Caribbean (one species). The Red Sea, the east coast of Africa, Madagascar, the Mascarene Islands, the Asiatic archipelago, various islands of warm regions of the Pacific, and finally the east coast of Central America is their true habitat.

\section{GENUS SCYTASTER}

This genus is a little less widespread than the genus Linckia. Like it, it is absent from Europe. But, moreover, it is completely absent from the coast of America. One species is found in the Red Sea and spreads from there into nearly all the Pacific (S. Agyptiacus Gray). The other species are at the Mascarene Islands, the Asiatic archipelago, the seas of China and New Caledonia. Finally, we must add one species at the Canary Islands ( $S$. Canariensis d'Orbigny), but it necessary to recognize its physiognomy differs very notably from that of the Scytaster from the Pacific. Gray formed for it the genus Narcissia. Never the less, Narcissia differs from Scytaster only in that their arms do not have a tubercular appearance like the latter. Basically, they have some analogy with Fromia, from which they are separated by the pyramidal form of their arms, the dimension of the arm relative to the disk and, more importantly, by the absence of marginal pates with a particular form and the arrangement of the ambulacral armature.

\section{GENUS FROMIA}

Fromia is restricted to the Red Sea, the Mascarenes and the Indian archipelago. One species $(F$. Balansa E. P.) occurs at New Caledonia, another at Japan. I must say that these species have a very great resemblance to each other. Perhaps the discovery of intermediate forms will result in combining some of them.

\section{GENUS METRODIRA}

This interesting little genus has still only two species, one (M. subulata Lamarck) that occurs in the Torres Strait and the other (M. subtilis Lütken) in the seas of China. 


\section{GENUS FERDINA}

Two species also, one from Mauritius and the other from the west coast of Colombia. This genus is very close to Scytaster.

\section{FAMILY GONIASTERIDÆ}

Taken as a whole and without considering of the number of diverse forms that inhabit the same locality, the family of Goniasteridæ could be apparently cosmopolitan. But if one goes down to analyze the genera, nearly all show, to the contrary, a very clear localization, of a kind that the mode of distribution of several of them is superimposed nearly exactly like that of genera we have studied in the previous families. This is an important result in the sense that it allows us to characterize large zoological provinces that study of families alone would not provide evidence.

In what follows, we will study the genera in an arrangement no longer in zoological order but in geographic order, beginning with those that are most northern.

\section{GENUS HIPPASTERIA}

Four species have been described, but the types that we have seen appear to us to be only unimportant varieties of Hippasteria plana, figured by Linck under the generic name of Pentaceros. This is the species often designated as Goniaster Phrygianus. It has been found in the greatest part of the north region of the Atlantic: Finland, coasts of Norway and England (deep water) in Europe, and Duck Island and the Bay of Fundy in America in the zone of madrepores.

This genus thus characterizes the northern part of the Atlantic.

\section{GENUS PORANIA}

We know that two species of this genus that, without going perhaps as far up in European seas as the preceding, coexist however with it to a certain extend in the Atlantic and, in our hemisphere, does not extend further south. These two species are: England.

1. Porania pulvillus O.-F. Müller from the coasts of Norway (Lofoden, Bergen) and

2. Porania Patagonica from the Bay of Borja (Patagonia) and the Strait of Magellan.

Thus our European species is found represented nearly in the same latitudes of the austral hemisphere at the south end of the American continent, by a congeneric species. We have already had the occasion to note a similar fact for the cribrellids and Solaster.

\section{GENUS PENTAGONASTER}

This genus is the most numerous of the family. All the efforts to divide it have resulted only with incomplete results. We include a part of Goniodiscus of Müller and Troschel and all the Astrogonium, except Astrogonium phrygianum that remains a Hippasteria. Thus constituted, it has species whose marginal plates are smooth, others whose marginal plates are granulose. It can happen that the ventral plates alone are smooth or that the dorsal plates are also. Gray used this character and some others, like the presence or absence of spines either on the plates of the disk or on the marginal plates to establish the genera Tosia, Pentagonaster, Astrogonum, Calliaster, Calliderma, and Stellaster. Genera based on very difficult characters can be questioned. However, 
it is very curious that certain established geographical regions correspond to them. As we define it, the genus Pentagonaster perhaps can be considered, to the contrary, as cosmopolitan.

We consider first the entirely granulose species to which Gray gave the name Astrogonium, which Müller and Troschel understood completely differently. There are four species in the North Atlantic from the coasts of England and Finland and three species in the Mediterranean. They are absent in warm regions but, as in Poranian, Solaster and the cribellids, we find them along the southern tip of the American continent, from Chile to Tierra del Fuego (four species), then at New Zealand (two species). It is true that another species occurs up to Port Essington in Australia ( $P$. paxillocus) and another up to the Fiji Islands. The first, however, has a special physiognomy and approaches that of Nectria from the Torres Strait and nearby regions. But we cannot say the same about $P$. spinulosus of the Fiji Islands, although Gray separated it from Astrogonium and placed it in his genus Hosea. On the other hand, we do not know the provenance of P. mammilatus that is attached to this group.

Thus the two principal stations that we just indicated in the northern and southern hemispheres cannot be considered absolute.

The species with smooth marginal and dorsal plates (Pentagonaster and Tosia of Gray) also have their own special location. This is around the Australian continent where they occur for the most part. One of them, P. pulchellus, is found again at New Zealand.

The species from the Chinese seas, Japan and the Asiatic archipelago also have their special physiognomy. They all belong to sections of Calliderma, Calliaster, Stellaster and Dorigona, all with more or less distinct arms, sometimes very elongated and a very particular dermal ornamentation.

One species, P. semilunatus, which makes up the genus Goniaster of Gray, is found in China, at Brazil, Senegal, Cape Verde and the Bissagos Islands. We will return to this remarkable distribution. It is eminently exceptional and does not invalidate what emerges from the study that we just made, to know that each of the principal forms that make up the genus Pentaonaster belongs to a particular geographic region, nearly always very clearly circumscribed.

\section{GENUS GONIODISCUS}

Goniodiscus, which is so closely attached to Pentagonaster by Stellaster, obeys this rule in the sense that they inhabit precisely the same geographic region as the latter.

\section{GENUS NECTRIA}

The only one whose exact provenance we know (N. ocellata E. P.) is from the Bass Strait.

The other genera of Goniasteridæ that remain to be discussed from a geographical point of view, are infinitely easier to circumscribe, as we see it, than the genus Pentagonaster. They are, indeed, less numerous in species and less rich in different forms.

\section{GENUS PENTACEROS}

The genus Pentaceros is, after the genus Pentagonaster, that with the greatest extension. One species, according to Müller and Troschel, occurs in the Adriatic, but it has not been found by any authors concerned with the fauna of this sea. However, as a species of this genera has actually been found at the Cape Verde Islands and one very abundantly in the Caribbean, it could very well be that Mediterranean also has some. We know two from the Red Sea. The number of species 
increases rapidly to the Mascarene Islands, where there are at least four. The Indian Ocean, the Asiatic archipelago, the northwest coast of Australia, and New Caledonia are among their preferred localities, exactly as we have seen for Linckia and Ophidiaster. Finally, two species inhabit the west coast of Central America.

Consequently, we can represent Pentaceros as inhabiting tropical seas and the warmer seas of temperate regions.

\section{GENUS NIDORELLIA}

Nidorellia, which seems to make the connection between Pentagonaster and Pentaceros, are peculiar to the west coast of Central America.

\section{GENERA CULCITA, RANDASIA, ASTERODISCUS}

Less numerous than Pentaceros, the culcites, although having an analogous geographic distribution, are however less widespread. We know of no species in the seas of Europe, on the west coast of Africa, or the east and west coasts of the Americas. But in the Red Sea we find Culcita coriacea M T., which lives along the entire coast of east Africa where it coexists with Culcita pentagularis Lamarck and perhaps with $C$. Schmideliana Retzius. In any case, we find these two latter species together at Mozambique and probably in the entire Indian archipelago because the first has been collected at the Fiji Islands and the second at the Moluccas and perhaps even, although this is still uncertain, at the Galapagos Islands.

Another culcitid, $C$. arenosa Val., occurs at the Hawaiian Islands, and Vélain, Rochefort and Isle have reported it from the crater itself of Saint Paul Island a curious species we have proposed to name $C$. Veneris.

The Indian archipelago is thus undoubtedly the true center of the culcitids. To the west, they extend to the east coast of Africa and are found to the base of the Red Sea. To the east, they read the Hawaiian Islands and perhaps the Galapagos archipelago. But it does not appear to have reached the west coast of America. They are thus much more confined than Pentaceros.

I believe Randasia Gray must be considered a young culcitid. We consequently have nothing to add regarding their origin.

Asterodiscus differs from the culcitids only by the presence of a naked plate on each side of each summit of the disk. The only specimen known is from the north-east of China.

\section{GENERA GYMNASTERIA, DERMASTERIAS AND ASTEROPSIS}

The genus Ggymnasteria includes only a few species, of which only one perhaps can be considered as well known. It is $G$. carinifera Lamarck. It has an area of occurrence nearly exactly superimposable to that of Mithrodia. It is encountered in the Red Sea, on the east coast of Africa, at the Mascarenes, New Caledonia, Hawaiian Islands and finally on the east coast of Central America. This is also the where Gymnasteria inermis Verrill, perhaps identical to our Dermasterias, is found. As for Gymnasteria inermis Gray, if is simply a young G; carinifera. Our G. valvulata from the Galapagos Islands is known only from a young individual. It is not sure that G. bisserrata von Martens is distinct from G. carinifera. Finally, G. imbricata Grube from Sitka is only another of our Dermasterias inermis, for which we had first taken it only with doubt. 
Asteropsis vernicina Lamarck, which has in common with G. valvulata a curious arrangement of pedicellariae, is from Panama and is encountered in consequence in the same region as $G$. cafinifera and in a region very near to $G$. valvulata.

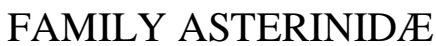

As in the family Asteriadæ, the genera in the family Asterinidæ are very different from the point of view of range. Asterina contains nearly all the known species and we only repeat about it what we have said of the family.

The genus Palmipes has only three very distinct species but whose distribution is very remarkable. One, $P$. membranaceus, inhabits European Seas, from the Channel to the Mediterranean. It has its equivalent at New Zealand in $P$. inflatus Hutton. Finally a magnificent multiarmed species, $P$. rosaceus Lamarck, inhabits Japan.

The genus Disasterina has only a single species from New Caledonia. We know two Patiria, of which one, the only one whose provenance is known, occurs at western Australia.

Of the three known Nepanthia, one comes from the Strait of Prince of Wales, another from Migupou.

Finally, Ganeria Falklandlica is perhaps Ctenodiscus at the Falkland Islands.

We do not know what Socomia Gray is or from where it came.

\section{FAMILY PTERASTERIDÆ}

Genus Pteraster. - Until now, only the genus Hymenaster Wyville Thompson has been accepted in the family Pterasteridæ, appearing not to differ in characters sufficiently from the true Pteraster. We will be disposed, however, to separate the latter, not the Hymenaster Wyville Thompson, but the Pteraster that have been described under the name P. Capensis Gray and P. cribrosus von Martens. It is to be noted, in fact, outside of all other results, that in these species the dermal membrane is supported not only by radiating calcareous spicules around a bony support, but by a network of ligaments that unite these spicules and form a more or less large mail that is always closed and perfectly distinct. In addition, these latter species reach an enormous size relatively to that of the true Pteraster and live in other geographic regions. These latter particularities cannot be considered as generic characters but they give more support to the zoological character than we reported at first. We can name these asteroids as a new group under the name Retaster.

That accepted, the true Pteraster are animals from arctic regions or deep water. Retaster belongs to warm waters of the Pacific and does not live in very deep zones, if I judge by the number of specimens that have been collected outside methodical research. Pteraster goes up to the north to Spitzberg, living along the coast of Greenland, Iceland, England, and Norway. One species inhabits the coasts of Florida, where it has been collected at $125 \mathrm{feet}$ depth. This fact is not isolated. Another form of cold regions, Solaser fucifer Düben and Koren, has been collected in the same region at 120 feet depth. Finally, another Pteraster is found at Rio de Janeiro (P. Dana Verrill).

Retaster comes from the Cape, Zanzibar and the Philippines. This is a region that we have had very often the occasion to refer and of which we will have a little later to indicate the characters from the point of view of the asteroid fauna.

FAMILY ASTROPECTENIDAE 
In this numerous family, three genera are very clearly characterized. These are the genera Chataster, Luidia and Ctenodiscus. Two, very distinct from these, have, to the contrary, the greatest similarity and differ only by the presence of an anus in Archaster and its absence in Asropecten. This character, which appears important in other groups, is perhaps much less important in asteroids where the anus is extremely reduced in relation to the development of the digestive system and appears, moreover, to have only a very unimportant physiological role. We are thus not astonished that many species have been assigned to one or the other of these two genera that could have been combined easily and that zoological geography shows us as widespread, both coexisting often in the same waters.

Archaster typicus and angulatus seem however to be slightly different from the others. They have pedicellariae lacking in European species of Archaster. Their anus is more visible and the pieces of their skeleton scarcely protrude, very notable differences from the special paxillae of the Astropectinidæ. These two species inhabit the Indian archipelago. The first goes up to Japan and extends towards the east to New Caledonia and the Tonga Islands. The Mascarene Islands, Java, the Philippines and Australia are the localities where the second has been collected up until now. Archaster Hesperus is from Japan. Archaster subinermis is from the Mediterranean. All the other six species are from northern regions of deep waters of the Atlantic.

Astropecten does not inhabit such cold waters. They do not appear to ascend into the glacial Arctic Ocean. No species is found from the southern point of the American continent whose extreme southern latitude would be New Zealand, where A. Edwardsi has been described. Except for that, all seas have some species of Astropecten and the Mediterranean does not seem the least well apportioned.

Luidia ascends perhaps a little less high towards the north than Astropecten, - but it is found at some depth in warm and temperate seas. There are usually only one or two species in the same region.

Chotaster, few in numbers, occupy a zone still more restricted: the Mediterranean, the Antilles and the Philippines. However, Grube has reported a species from California, whose provenance requires verification.

Finally, contrary to the preceding genera, the genus Ctenodiscus is restricted to cold waters: Finland, coasts of Norway, Greenland, etc. Another has been collected in Patagonia and described by Doctor Lütken.

Thus four zones can be established corresponding to the four principal genera of the family Astropectinidæ. The first is very restricted, wider however than the tropical region where there are the genera Choetster, Luidia and Astropecten. The second, exceeding the first, has Luidia and Astropoecen. Finally a third, still more extensive, is inhabited by Astropecten. Outside these three overlapping zones are the polar caps whose limited region is inhabited by Ctenodiscus and some Archaster.

\section{FAMILY BRISINGIDÆ}

The only species in the genus Brisinga are from deep regions of the Atlantic (Lofoden Islands at the coast of Portugal). 


\section{SUMMARY}

If we now look at all the facts on the geographical distribution of the genera of asteroids, here is what is clear. Some genera can be considered cosmopolitan. Others, to the contrary, inhabit more or less restricted areas of the globe. The cosmopolitan genera should be considered as those that best respond to the varied conditions that may be present in the seas. The others, to the contrary, are restricted to more or less limited regions of the globe. The cosmopolitan species should be considered as those that adjust best to the effects to the various conditions of the seas, as those that resist best the effects of the environment, those that, in a word, have the greatest organic resistance. But they are also those that have the greatest number of species, those consequently that have the maximum plasticity. The coincidence of these two facts is not without interest, because we can ask if they are not connected by a cause and effect, if the reason for the great extension of these genera is not found precisely in the facility with which the forms that compose them, without being very distant from a common type, have been able to adapt to the most varied biological conditions. It is thus important, consequently, to establish by numbers what we are going to say. The genera that can be considered as nearly cosmopolitan are Asterias, Pentagonaster, Asterina and Astropecten. The first has 82 species, the second as 34, the third 31, the fourth 63. In all, 210 species, i.e., nearly half the total number of 443 species. As the total number of genera is 51 , we see that, for the 47 remaining genera, there are more than 235 species, i.e. an average of five species per genus while the four first have, to the contrary, an average of 52, five species per genus, more than ten-fold.

It is obvious that in these cosmopolitan genera, the effect of climate, of the average temperature has little effect on the distribution of the species, although it is, however, possible to emphasize it. Other species show, to the contrary, the influence in a very marked fashion. Within certain limits of latitude, they are encountered all around the globe. There are some genera whose resistance is considerable as certain conditions of temperature and light occur. It should be noted they come immediately after the four that we just discussed relative to the number of species that indicate their degree of plasticity. They are the genera Echinaster, Linckia, Ophidiaster, Pentaceros, Culcita and Luidia that have the following number of species:

$\begin{array}{lr}\text { Echinaster } & 15 \\ \text { Linckia } & 16 \\ \text { Ophidiaster } & 19 \\ \text { Culcita } & 7 \\ \text { Pentaceros } & 31 \\ \text { Luidia } & \underline{14} \\ \text { Total } & \underline{102}\end{array}$

There is an average of seventeen species per genus. But these six genera added to the four preceding make in all only ten genera. There remains consequently 41, among which are distributed 133 species. That makes only 3.2 species per genus, although those of the first series contain nearly 53 and those of the second, seventeen. This average would decrease again if one confused, as could be done easily, Archaster with Astropecten. These remaining genera are made up in general of species that are only few in number but also extremely regional. There are, however, some exceptions that must be studied in the genera Acanthaster, Mithrodia and Gymnasteria, exceptions to which we cannot call too much attention but which do not invalidate 
the generality of the law that, in asteroids: the genera have in general a greater geographical extension as they increase in number of species.

The richest genera and the most invasive are nearly indifferent to climatic conditions. Next come genera that require an average high temperature but that seem indifferent to the greatest number of biological conditions. Finally, genera that are very poor in species are also, as a rule, very circumscribed and seem to be able to adapt to only to specific biological conditions. It is interesting to see very frequently forms belonging to these genera correspond at the same latitude in the two hemispheres, such occurs for cribrellids, Porania, Palmipes and Ctenodiscus.

Among those genera whose geographical distribution is limited, only one can be considered restricted to the Atlantic, Hippasteria so close, moreover, to Pentagonaster. The genera Heliaster, Labidiaster, Demasterias, Asteropsis, Amphiaster, and Nodorellia are restricted to the west coast of the Americas while the east coast has only a single genus that is restricted to it. Calvasterias and Anasterias, unimportant varieties of the type of the genus Asterias. Acanthaster, Mithrodia, Fromia, Metrodira, Ferdina, Asterodiscus, Culcita, Nectria, Goniodiscus, Anthenea, Gymnasteria, Disasterna, Patiria, and Nepanthia are restricted to the Pacific and to their adjacent seas (sixteen genera). This is sufficient to show how much greater is the variety of types in this region than in the Atlantic. This variety coincides precisely with the very much greater extension of the warm regions and a variety also is also very much greater in the biological conditions, a variety that is related to the large number of islands and archipelagos, of gulfs and arms of the seas that are part of the Grand Ocean.

These are the striking coincidences. We cannot go back further in our search for the causes that led to the geographic distribution of these groups that we call genera. What is the basis of these groups, themselves? We do not know. These two questions are connected, are perhaps susceptible to clarification, the one by the other. But their solution, which we still do not know how to solve, far from it, is lost in the distant past.

\section{GEOGRAPHICAL DISTRIBUTION OF SPECIES}

In spite of the large number of definitions given for species, we still have no criterion, applicable in all cases, how to recognize with certainty, the individuals that belong to the same species. I.e., those that are descended from a common ancestor and that, reproducing, are apt to provide fertile offspring. On the other hand, the criterion of unlimited fertilization is very often inapplicable. On the other hand, the genealogical criterion is no less. It is impossible to clearly limit the degree of similarity or dissimilarity that individuals coming from the same parents can have, and it is no less embarrassing when it is necessary to distinguish between individual characters and truly specific characters.

This is one of the greatest difficulties encountered when one wants to define the area inhabited by a species. This difficulty for little studied asteroids, often described insufficiently, shows itself to the highest degree. Our European species even are still from being well known. No one has dared to decide whether, for example, if Asterias rubens and Asterias violacea, are the same species or not. Pentagonaster granularis, $P$. aculeatus, and $P$. borealis perhaps are perhaps only a single species, and the fact seems certain for Hippasteria plana, H. Europaca and $H$. Abbensis. Likewise, the exact number of species of the west coast of the Americas is still to be established. If this is so for the species that eminent naturalists have frequently studied, one understands that it doubtful for most others. This is especially true for the species that have a vast distribution and in which local varieties frequently occur. Finally, several inadequately described 
species have only a doubtful validity. We must remember all these facts in order to show that we cannot consider the results we are going to show as having a definitive value. These results are given in the lists given above that include the names of all species that have provisionally accepted.

We have been able to examine many of these species but I have not seen everything and we realize there are many that new study will lead to their non-acceptance. Other names, to the contrary, are not there because we are sure they are duplicates used with older names. We review these in Révisions des Stellérides du Muséum (Archhives de Zool. Expérimentale, IV and V) and the table of concordance that ends the latter work.

As it is, this lists represents the present state of our knowledge on the species names of asteroids and the localities where each is found. The number of nominal species is 445 .

Here are the general observations that the reading of this list suggests.

Between the east coast of North America and the European coast of the Atlantic, we find common species like the hyperboreal species or those of deep waters, i.e., Cribrella oculata, Hippasteria plana and Pteraster militaris. von Martems thought he found Cribrella oculata at Java and Isle de Flores. There is indeed a cribrellid at the Cape of Good Hope, Campbell Island and New Zealand., but we will consider it as distinct from $C$. oculata. We have described it under the name $C$. ornata, and it is probable that the specimens observed by von Martens should be referred to it. With this reservation, we can say that the three species just discussed do not reach into America below the Bay of Funday. In Europe, they barely reach the Channel, where Cribella oculata is the only one encountered. No Asterias, no Echinaster, no Asterina, and no Astropecten are common to the two coasts. In summary, from the Bay of Funday to Florida, no American species is found on the opposite coast of the Atlantic. We will soon see that things are modified a little below Florida. But we return to European seas.

A theory, although the facts have long been invalidated, requires that no sedentary animal is common to the Mediterranean and the Atlantic. The starfish contradict this. Truthfullly, Asterias rubens that is found on the entire European coast of the Atlantic and descends to Senegal, does not appear in our great interior sea. But A. glacialis, which extends however to Finland, is abundant there and has many varieties, to each of which Valenciennes has given a name in the collection in the Museum. Asterias glacialis descends, moreover, very low in the Atlantic and I would not be far from considering, as simple local varieties of this species, the A. madeirensis Stimpson that inhabits Madeira in spite of the very clear but unimportant characters that it has, and even $A$. Webbiana d'Orbigny collected by Webb and Berthelot at the Canary Islands.

Another Mediterranean asteroid species surely penetrates into the Atlantic. This is $A$. tenuispina, collected at Madeira by de Castelneau, now vice-consul of France at Melbourne (Australia), at the Canaries by Webb and Berthelot, at the Cape Verde Islands by Bouvier, and which has also been reported at the Bermudas by Dr. Lütken. These facts agree perfectly with the others we can report now. Ophidiaster ophidianus inhabits the Atlantic and is encountered in the Atlantic at the Canary Islands (Webb and Berthelot) and the Cape Verde Islands (Bouvier). Echinaster sepositus seems, to the contrary, goes north of the Strait of Gibraltar. It is in the Bay of Biscay (Fischer) and in the Channel, at Roscoff (Perrier) where it has been encountered. But we must receive, with an infinitely greater reserve, indications that A. tenuispina inhabits Mauritius, Java, the Mollucas, Australia, and finally on the coast of China and Hong Kong. It should be noted that Asterias calamaria inhabits this same region and perhaps by other species, whose young have a very great resemblance with adult $A$. tenuispina, could be confused easily with it.

von Martens again indicated that Asterias rubens is found in Japan. But no other fact has confirmed this. 
Here is another analogous geographic distribution, to which I have reservations. In the family Asterinidæ, there are two species known in the Mediterranean and the Atlantic: Palmipes membranaceus and Asterina gibbosa. The first has not been found elsewhere but, according to Michelin, Peters, and von Martens, A. gibbosa is also found in the Red Sea, the Mozambique Strait, Mauritius, Flores Island, the Philippines, and finally the Moluccas. I am very astonished to have encountered no specimens from these locations either in the collection of the Jardin des Plantes or in that of the British Museum, which contains, however, many other Asterina from these locations. The collection of Michelin itself has none. Michelin has recorded the Ophidiaster ophidianus as inhabiting Mauritius, but he apparently confused it with $O$. Leachii in his collection. On the other hand, a figure of Savigny, that Müller and Troschel referred to A. gibbosa, that they named Asteriscus verruculatus, is really in the most recognizable fashion A. cephea Valaenciennes, which is abundant in all collections. What is this species that has been taken by the authors in question for a true A. gibbosa? We can respond that these same authors also report $A$. cephea, but we never find a remarkable and however very common species, $A$. wega, that is not without some relation with $A$. cephea. Is it to it that the latter names has been used? These of the questions that must be resolved and that we would like to see examined again.

It should be noted, indeed, that A. tenuispina and A. gibbosa are the only common species that have been reported between the Mediterranean and the Red Sea or in the Pacific. If the observations just presented lead to the recognition that the two Mediterranean species are really distinct from those of the Red Sea and the Pacific to which their names have been applied, we arrive at this important rule that no asteroid is common to the Mediterranean and the Red Sea, whose fauna has, moreover, from this point of view, characters absolutely different, that the presence of some common species does not suffice to erase. And yet some species of mollusks are common to the Red Sea and the Mediterranean. Ehrenberg and Hemprich cites no less the 74 out of 408 , nearly a sixth.

If all the species of asteroids common to the Mediterranean and the Red Sea are still doubtful, we have had, to the contrary, to mention several species common to the Mediterranean and the warm and temperate parts of the Atlantic. We can now increase this number to at least one species of Astropecten, A. serratus Valenciennes, which is found at Marseille, in the Bay of Biscay and at Rochelle. Luidia ciliaris should also be part of this list, making a total of seven species. On the other hand, we have seen that one of these species, A. tenuispina, reaches as far as Bermuda. It has not been reported further. But it is not the same for some species that coexist with it at the Cape Verde Islands or on the African coast of the Atlantic. I want to speak of Lickia Guildingii Gray, Pengtagonaster semilunatus Linck, Aserina stellifera Mobius, and finally Luidia senegalensis M. T. These species cross the Atlantic and are found on the coast of America: $L$. Guildingii at Bermuda, the Antilles, the Gulf of Mexico (Vera Cruz) and on the coast of Brazil (Bahia); P. semilunatus at the Antilles and on the coast of South Carolina (Charleston); A. stellifera at Brazil (Rio Janeiro); and finally L. senegalensis, likewise at Brazil.

These are the American specimens that have been described: Ophidiaster ornithopus Valenciennes, Scytaster stella Duchassaing, Goniaster americanus Verrill, Asteriscus marginatus Valenciennes (a name that should be retained), Asteriscus brasiliensis M. T., and Luidia Marcgravii Lütken. Even though some details can be used to support these species, the fact of the exact correspondence of some similar forms on the two coasts of the Atlantic is striking proof of their identity. This fact becomes even more important if we note that the different places where these forms are found are placed precisely on the path of the great current that leaves the Gulf of Guinea, runs along the north coast of Brazil, and goes along the coast of central America to the 
base of the Gulf of Mexico, and is reflected to return to the African coast after forming the Gulf Stream that passes by the Azores and Madeira, and the great north equatorial current that ends at the Cape Verde Islands.Thanks to this current that constantly mixes the American waters with those of the African coasts, the species inhabiting these waters should be transported easily from one coast to the other of the Atlantic. It is thus quite natural that we find some of them entrained in its path and, moreover, the fact is not restricted to the asteroids.

Neritina viridis and Columbella cribraria, among the gastropod mollusks, is found in the Antillles, at Madeira, and the Canary Islands, and it is known that several species are considered as common to the Antilles and to Sicily. Even some terrestrial mollusks (Helix advena, Bulimus boeicatus, B. badiosus) are common to the Canaries and some islands of the Antilles. Although the fact of the existence of the some species on the east and west coasts of tropical part of the Atlantic is not very surprising in that it concerns starfish and we are led to the explanation of the fact by this other, that if in the circumpolar region there are common European and American species, that is that there are none in the average or temperate zone. The influence of the equatorial currents and the Gulf Stream emphasizes this as clearly as possible.

We have successively supported and rejected the existence of species common to the eastern and western coasts of America. We do not know a single species of starfish that shows this, not even a single species of one of the coasts that that can considered as near a species of the opposite coast. We have seen, to the contrary, that many genera are restricted to the west coast. We would not want to support, in regard to echinoderms, another proposition advanced by Darwin regarding mollusks, i.e., no species is common to the west coast of America and the Pacific islands. To make the phenomenon that we have reported more striking, we must study first the mode of distribution of species in the Red Sea and across the Pacific archipelagos.

If we do not find species that should surely be considered as occurring at the same time in the Mediterranean and the Red Sea, we see, to the contrary, a good number of these species descending the length of the African coast, reaching Madagascar, the Mascarene Islands, to extend over all of Malaysia and even to the northern coast of Australia and then passing to New Caledonia and the Fiji Islands. To the north they are found again in the Hawaiian Islands. It is from there that they reach Central American in the region of Panama, that has some analogies in detail with the Indo-Pacific region.

This is certainly the case for Gymnasteria carinifera that we have been able to examine authentic individuals coming from the Red Sea, Mauritius, Amboine, New Caledonia, the Fiji Islands, the Hawaiian Islands, and Panama.

Considering the reports of the genera Linckia, Acanthaster, and Mithrodia, we are struck by the coincidence of the following species:

Lickia diplax

Acanthaster echinites

Acanthaster Ellisii

Mithrodia clavigera

Mithrodia Bradleyi
Mascarenes, Madagascar, New Caledonia, California

Philippine Islands (Mindanao), Moluccas

(Ternate, Amboine) Sunda Islands (Java, Sumatra), Fiji Islands

La Paz, Ecuador, Galapagos Islands

Mascarenes, Java, Flores, Moluccas, Tahiti, Hawaiian Islands

Panama 
If one accepts that the two Acantaster species and the two Mithrodia species are one and the same species, we that the geographical distribution of Acanthaster and that of Mithrodia in question are identical to that of the well authenticated Gymnasteria carinifera.

It is mostly because of the difference in habitat that Doctor Lütken has proposed to distinguish the Acanthaster of the Pacific from that of Panama, and the individual that we ourselves have designated A. Eellisi, because of certain zoological characters, not considering provenance. The question remains and the probabilities are to the contrary that the Acanthaster of America and that of the Pacific are the same species.

Regarding Mithrodia, we find two very distinct forms in the collections. One has narrow arms, elongated spines covering their entire length except at the top, small scales forming five rows of which the dorsal median one and the two adjacent ones are in general very incomplete. Tubercles covered with a very small number of granules ae scattered on the skeletal ossicles, particularly on the nodes between the spines. - In the other form, the arms are more robust, the spines much shorter, and their three dorsal rows are less distinct. The spines that form them are not much different from the other tubercles on the skeletal ossicles. All are covered by a very large number of granules. All these give together a very different physiognomy. But, basically, these characters are the only differences in the development of the same parts. It should be noted that the essential characters, the identical number of spines of each interambulacral plate remains the same. Several specimens recently received from the Hawaiian Islands at the museum of Paris belong to the second type. Some analogous individuals have been considered a distinct species under the name $M$. clavigera by Horace Mann, who kept for Asiatic individuals of the first type, the name of $M$. spinulosa Gray. Now, these $M$. clavigera do not differ from a Panamanian individual whose label I have seen at the British Museum, Mithrodia Bradleyi Verrill. If we stopped at these identifications, we would thus have three species of Mithrodia. But I must remark that M. Bradleyi and M. clavigera must have been confused. The latter and $M$. spiniuola occur together at several localities. Will we not find intermediate forms and that these three nominal species must be combined into one whose geographical distribution would be the same as that of Acanthaster echinites and Gymnasteria carinifera? This manner of seeing is not improbable and, moreover, it is not accepted. It remains no less interesting, from the point of view of the idea of the species, to see forms so very close replace each other in an area of distribution that can be completely occupied by one species of another genus. Inevitably, it raises the question of a genealogical relationship between these forms.

Other species occupy a less vast area but that coincides partially with the preceding.

We have not spoken here of the family Asteriadæ of which the Pacific Ocean has only rare forms; but in the other families we find the following distributions.

$\begin{array}{ll}\text { Echinaster fallax } & \text { Red Sea. Zanzibar, Timor, Philippines, } \\ & \text { Querimba, New Zealand } \\ \text { Fromia milleporella } & \text { Red Sea, Reunion Island, Madagascar, } \\ & \text { Moluccas } \\ \text { Linckia miliaris } & \text { Red Sea, Mozambique, Mauritius, Flores, } \\ & \text { Timor, Celebes, Philippines, north of } \\ \text { Linckia multifora } & \text { Australia, New Caledonia } \\ & \text { Red Sea, Mozambique, Mauritius, Larentuka, } \\ \text { Linckia pacifica } & \text { Celebes, Moluccas, New Caledonia, Hawaiian } \\ & \text { Islands } \\ & \text { Nicobar Islands, Samoan Islands, Tahiti }\end{array}$


Ophidiaster pusillus
Culcita pentagularis
Pentaceros muricatus

---- turritus

Asterina cephea

Archaster typicus

Astropecten polyacanthus
Flores, Moluccas, Philippines, New Caledonia Mozambique, Torres Strait, Fiji Islands

Zanzibar, Madagascar, Seychelles Islands, Mascarenes, Timor, Larentuka, near Flores, Moluccas

Zanzibar, Mascarenes, Moluccas, New guinea, New Caledonia

Red Sea, Zanzibar, Mozambique, Iho, Java, Philippines, New Caledonia

Japan, Moluccas, Flores, Timor, Australia, New Caledonia, Tonga island

Japan, Ceylon, Red Sea, Australia, New Zealand

It is all one fauna of starfish that characterizes a well determined region of the globe, and to which can be added some species of less extended regions, species characterizing secondary regions.

One species seems to escape the rules, which stands out from the preceding. Its geographical distribution seems to justify what has been attributed to Asterias rubens and A. tenuispina. I want to speak of Pentagonaster semilunatus. We have already encountered it at the Cape Verde Islands, Bissagos Islands, and at Senegal and on the east coast of America. Its distribution conforms to that of the preceding species. But we find this same Pentagonaster at Zanzibar, the Malaysian islands and finally in China. I.e., that it has as extensive a distribution in the great region of the Pacific that we have just outlined, that in the tropical region of the Atlantic. It is a fact unique in the history of starfish. It would be surprising if one of the groups of echinoderms that have been better studied show analogous facts. Here is distribution of an echinid reported by Alexander Agassiz:

\section{Diadema setosum}

Cape Verde Islands, Indian Ocean, Fiji Island, Hawaiian Islands, Japan

It is equally isolated in this group, where we find, moreover, the grand general facts that we have reported for starfish. In the tropical region of the Atlantic, we see indeed the following species of urchins passing from the African coast to the American coast of this ocean.

\section{Arbacia pustulosa \\ Diadema setosum \\ Echinometra subangularis \\ Echinocardium cordatum \\ Brissus unicolor}

We also see Echinanthus testudinarius and Metalia maculosa common the Pacific islands and the west coast of America. As to the species common to the largest part of the islands of the Asiatic archipelago, they are just as numerous as in the starfish families and can, like them, go up to the Red Sea and extend to New Caledonia or to the Hawaiian Islands.

Such are the general fact on the geographical distribution of the species. As to specific facts, the extensiveness of each species, this is easily seen in the following list that summarizes all the 
information that we have been able to obtain. The bathymetric information is so little that we do not believe it is useful to mention it.

List of known asteroid species and information on the principal locations where they have been found up to this day.

\section{ASTERIADÆ}

\section{GENUS ASTERIAS LINNÉ}

\begin{tabular}{|c|c|c|c|}
\hline 1 & Asterias & acervata Stimpson & Behring Strait \\
\hline 2 & ---- & acutispina Stimpson & Ousima Island \\
\hline 3 & ---- & æqualis Stimpson & Monterey (California) \\
\hline 4 & ---- & africana Müller and Troschel & Cape of Good Hope \\
\hline 5 & ---- & amurensis Lütken & Tartary Channel \\
\hline 6 & ---- & antarctica Lütken & Strait of Magellan \\
\hline 7 & ---- & arenicola Stimpson & $\begin{array}{l}\text { Long Island, Carolina, } \\
\text { Georgia }\end{array}$ \\
\hline 8 & ---- & aster Gray & $?$ \\
\hline 9 & ---- & borealis E. Perrier & Labrador \\
\hline 10 & ---- & bootes Müller and Troschel & $?$ \\
\hline 11 & ---- & borbonica E. Perrier & Reunion Island \\
\hline 12 & ---- & brevispina Stimpson & San Francisco \\
\hline 13 & ---- & brachiata E. Perrier & Gulf of Georgia \\
\hline 14 & ---- & calamaria Gray & $\begin{array}{l}\text { Mauritius, Australia, New } \\
\text { Zealand }\end{array}$ \\
\hline 15 & ---- & capensis Stimpson & South Africa \\
\hline 16 & ---- & capitate Stimpson & San Diego, California \\
\hline 17 & ---- & clavata Philippi & Chile \\
\hline 18 & ---- & compta Stimpson & New Jersey (deep water) \\
\hline 19 & ---- & conferta Stimpson & Puget Strait \\
\hline 20 & ---- & Cunninghami E. Perrier & $\begin{array}{l}\text { Punta Arenas (Strait of } \\
\text { Magellan }\end{array}$ \\
\hline 21 & ---- & cribraria Stimpson & Behring Strait \\
\hline 22 & ---- & echinata Gray & Valparaiso \\
\hline 23 & ---- & disticha Brandt & Kamschatka \\
\hline 24 & ---- & epichlora Brandt & $\begin{array}{l}\text { Sitka Island, Puget Strait, } \\
\text { mouth of the Oregon }\end{array}$ \\
\hline 25 & ---- & Farbricii Al. Agassiz & Labrador \\
\hline 26 & ---- & fissispina Stimpson & Shoal-water Bay, Oregon \\
\hline 27 & ---- & Forbesii Desor & $\begin{array}{l}\text { Grand Menan, Eastport } \\
\text { (Maine), Chelsea, Beverly }\end{array}$ \\
\hline 28 & ---- & fulva Philippi & Chili \\
\hline 29 & ---- & fungifera E. Perrier & Australia \\
\hline 30 & ---- & gelatinosa Meyen & Chili, Bolivia (Mejillones) \\
\hline 31 & ---- & gemmifer Valenciennes & Chile \\
\hline
\end{tabular}




\begin{tabular}{|c|c|c|c|}
\hline 32 & ---- & Germani Philippi & Chile \\
\hline 33 & ---- & gigantea Stimpson & Oregon \\
\hline 34 & ---- & glacialis Linné & $\begin{array}{l}\text { Finland, Iceland, the entire } \\
\text { Atlantic coast of Europe, } \\
\text { Mediterranean, Canary } \\
\text { Islands, Cape Verde Islands }\end{array}$ \\
\hline 35 & ---- & globifera Gray & Tasmania \\
\hline 36 & ---- & granifera Lamarck & Australia, Tasmania \\
\hline 37 & ---- & grœnlandica Steenstrup & Greenland \\
\hline 38 & ---- & hexactis Stimpson & Strait of Puget \\
\hline 39 & ---- & hispida Pennant & North of the Atlantic \\
\hline 40 & ---- & japonica & Japan \\
\hline 41 & ---- & janthina Brandt & Sitka Island \\
\hline 42 & ---- & Jehennesii Valenciennes & Madagascar \\
\hline 43 & ---- & Kamschatika Brandt & Kamschatka \\
\hline 44 & ---- & Katherinæ Gray & Oregon? Labrador? \\
\hline 45 & ---- & Linckii Müller and Troschel & $?$ \\
\hline 46 & ---- & littoralis Stimpson & Eastport (Maine) \\
\hline 47 & ---- & lurida Philippi & Chile \\
\hline 48 & ---- & Lütkeni Stimpson & Oregon \\
\hline 49 & ---- & Madeirensis Stimpson & Madeira \\
\hline 50 & ---- & margaritifer Müller and Troschel & $?$ \\
\hline 51 & ---- & meridionalis E. Perrier & Antaractic seas \\
\hline 52 & ---- & mexicana Lütken & Mexico \\
\hline 53 & ---- & mitis Philippi & Chile \\
\hline 54 & ---- & mollis Hutton & New Zealand \\
\hline 55 & ---- & Mülleri Sars & Finland, coasts of Norway \\
\hline 56 & ---- & Ochotense Brandt & Kamschatka \\
\hline 57 & ---- & ochracea Brandt & $\begin{array}{l}\text { Sitka Island to San } \\
\text { Francisco }\end{array}$ \\
\hline 58 & ---- & pallida Al. Agassiz & Chelsea, New Jersey \\
\hline 59 & ---- & paucispina Stimpson & Strait of Puget \\
\hline 60 & ---- & pectinata Brandt & Kamschatka \\
\hline 61 & ---- & polaris Müller and Troschel & Greenland \\
\hline 62 & ---- & polyplax Müller and Troschel & Tasmania \\
\hline 63 & ---- & rarispinus E. Perrier & Cape of Good Hope \\
\hline 64 & ---- & Rodolphi E. Perrier & Kermandec Islands \\
\hline 65 & ---- & rubens Linné & $\begin{array}{l}\text { European coasts of the } \\
\text { Atlantic, Senegal, Japan } \\
\text { (von Martens fide) }\end{array}$ \\
\hline 66 & ---- & rugispina Stimpson & $\begin{array}{l}\text { Strait of Magellan, Tierra } \\
\text { del Fuego }\end{array}$ \\
\hline 67 & ---- & scaber Hutton & New Zealand \\
\hline 68 & ---- & sertulifera Xanthus & $\begin{array}{l}\text { Margarita Bay, Cape San } \\
\text { Lucas (California) }\end{array}$ \\
\hline 69 & ---- & sinusoida E. Perrier & Hobart Town, (Tasmania) \\
\hline
\end{tabular}




$\begin{array}{llll}70 & ---- & \text { spectabilis Philippi } & \text { Chiloe Islands } \\ 71 & ---- & \text { stellionura Valenciennes } & \text { Spitzberg } \\ 72 & ---- & \text { Stimpsoni Verrill } & \text { Eastport (Maine) } \\ 73 & --- & \text { sulcifer Valenciennes } & \text { Tierra del Fuego } \\ 74 & ---- & \text { tenera Stimpson } & \text { Massachusetts Bay, } \\ & & & \text { Eastport (22 feet depth) } \\ 75 & ---- & \text { tenuispina Lamarck } & \begin{array}{l}\text { Mediterranean, Madeira, } \\ \text { Canaries, Cape Verde } \\ \end{array} \\ & & & \text { Islands, Bermudas, reefs of } \\ & & & \text { Abrohlos, Mauritius } \\ & & \text { Michelin fide) Java, } \\ & & & \text { Mollucas, Australia, Hong } \\ & & & \text { Kong (von Martens fide) } \\ 76 & ---- & \text { Troschelii Stimpson } & \text { Strait of Puget } \\ 77 & ---- & \text { Vancouveri E. Perrier } & \text { Vancouver Island } \\ 78 & ---- & \text { varia Philippi } & \text { Chili } \\ 79 & --- & \text { violacea O.-F. Müller } & \text { North of the Atlantic to } \\ & ---- & & \text { Finland } \\ 80 & & \text { vulgaris Stimpson } & \text { Labrador (inclusive) to } \\ & ---- & & \text { Cape Cod } \\ 81 & ---- & \text { Webbiana d'Orbigny } & \text { Canary Islands } \\ 82 & & \text { Wilkinsoni Gray } & \text { North of Africa } \\ & & & \\ & & \text { II. GENUS ANASTERIAS E. PERRIER }\end{array}$

83 Anasterias nuda E. Perrier ?

III. GENUS CALVASTERIIAS E. PERRIER

84 Calvasterias asterinoides E. Perrier Torres Strait

IV. GENUS HELIASTER GRAY

85 Heliaster

86

87 Asterias

88

89

90 canopus Valenciennes

Cumingi Gray

helianthus Lamarck

Kubiniji Xantus

microbrachia Xantus

multiradiata Gray
Juan Fernandez Islands

Galapagos Islands

Payta, Callao, Caldera, Valparaiso

Margarita Bay, La Paz, Cape San Lucas, Mazatlan, Acapulco, Hawaiian Islands Margarita Bay, Cape San Lucas, Pearl Island, Panama Galapagos Islands 


\section{GENUS PYCNOPODIA STIMPSON}

91 Pycnopodia helianthoides Bramdt

Sitka Island, Strait of

Puget, Gulf of Singio,

Tomales Bay (California)

VI. GENUS LABIDIASTER LÜTKEN

92 Labidiaster radiosus Lovén Patagonia

VII. GENUS PEDICELLASTER SARS

93 Pedicellaster .....

VIII. GENUS STICHASTER MÜLLER AND TROSCHEL

$\begin{array}{llll}94 & \text { Stichaster } & \text { albulus Stimpson } & \text { Greenland } \\ 95 & ---- & \text { aurantiacus Meyen } & \text { Callao, Chile } \\ 96 & ---- & \text { australis Verrill } & \text { New Zealand } \\ 97 & ----- & \text { roseus O.-F; Müller } & \text { Coasts of England and } \\ & & & \text { Norway }\end{array}$

\section{ECHINASTERID $Æ$}

IX. GENUS ACANTHASTER PAUL GERVAIS

98 Acanthaster echinites Gray

Philippine Islands

(Mindanao), Moluccas

Islands (Ternate,

Amboine), Sunda Islands

(Java, Sumatra), Fiji

Islands

99 ---- $\quad$ Ellisii Gray

La Paz, Ecuador,

Galapagos Islands

100

Solaris Ellis

Strait of Magellan

X. GENUS CRIBRELLA AGASSIZ

Cribrella lœviuscula Stimpson

102

oculata Linck
Strait of Puget, Oregon

Finland, coasts of

Norway and England, 
Channel, Greenland,

Labrador, Grand Menan,

Bay of Fundy, Nantucket

Island, Eastport (Maine),

Java, Timor (von

Martens fide)

103 ---- ornata E. Perrier

Cape of Good Hope,

Campbell Island, New

Zealand

104 ---- $\quad$ Sarsii Müller and Troschel Bergen

XI. GENUS ECHINASTER MUULLER AND TROSCHEL

\section{Echinaster}

$\begin{array}{ll}106 & ---- \\ 107 & ---- \\ 108 & ---- \\ 109 & ----\end{array}$

110

111

(10)

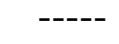

113

114

115

116

117

118

119

\author{
brasiliensis Müller and \\ Troschel \\ crassus Müller and Troschel \\ cribrella Lütken \\ deplantus Grube \\ echinophora Lamarck
}

eridanella Valenciennes

fallax Müller and Troschel

serpentarius Valenciennes

spinulosus Verrill

ternuispinus Verrill

vestitus E. Perrierm
Rio Janeiro

?

Chili

?

Virginia, Yucatan

(Belize), Bahia, Rio

Janeiro

New Ireland, New

Caledonia

Red Sea, Zabzibar, Tinnor, Philippines

(Luzon), Querimba, New

Zealand

Madagascar

?

Florida

Coast of Brittany

(Roscoff), Bay of Biscay, Mediterranean

Vera Cruz

Florida

La Paz

Mayotte Island

\section{GENUS MITHRODIA GRAY}

120 Mithrodia

121

122
Bradleyi Verrill

clavigera Lamarck
Panama

Mascarene Islands, Java, Flores, Moluccas, Tahiti Hawaiian Islands 


\section{GENUS SOLASTER FORBES}

$\begin{array}{ll}123 & \text { Solaster } \\ 124 & ----- \\ 125 & ----- \\ 126 & ----- \\ 127 & -----\end{array}$

128

129

130 -----

\author{
alboverrucosus Brandt \\ affinis Brandt \\ decanus Müller and Troschel \\ decemradiatus Brandt \\ endeca Linck
}

furcifer Düben and Koren

gracilis Grube

papposus Linck
Behring Strait

Behring Strait

Southeast of Australia

Sitka Island

Finland, coasts of

Norway and England,

Greenland, Labrador,

Bay of Fundy, coast of

Maine, Massachussets

Bay

Deep waters of the

Atlantic

Hong Kong

Finland, coasts of

Norway and England,

Channel (Roscoff),

Greenland, Labrador,

Bay of Fundy,

Massachusetts Bay

\section{LINCKIADÆ}

XIV. GENUS FERDINA

131 Ferdina

132

-----

$\begin{array}{ll}133 & \text { Fromia } \\ 134 & ---- \\ 135 & ---- \\ 136 & ----\end{array}$

\begin{tabular}{ll}
137 & ---- \\
138 & ---- \\
139 & ---- \\
& \\
\hline
\end{tabular}

Cumingii Gray

flavescens Gray

\section{GENUS FROMIA}

\author{
Balansæ E. Perrier \\ indica E. Perrier \\ japonica E. Perrier \\ milleporella Lamarck
}

monilis Valenciennes

(Metrodira) subtilis Lütken

----- subulata Lamarck
West coast of Colombia Mauritius

New Caledonia

Indian Ocean

Japan

Red Sea, Reunion

Islalnd, Madagascar,

Moluccas

Amboine

Chinese seas

Torres Strait, George

Sound (Australia)

\section{GENUS LINCKIA}

140 Linckia Bouvieri E. Perrier

Cape Verde Islalnds 


\begin{tabular}{|c|c|c|c|}
\hline 141 & ----- & diplax Müller and Troschel & $\begin{array}{l}\text { Mauritius, Madagascar, } \\
\text { New Caledonia, } \\
\text { California (?) }\end{array}$ \\
\hline 142 & --- & $\begin{array}{l}\text { Ehrenbergi Müller and } \\
\text { Troschel }\end{array}$ & Red Sea, Mozambique \\
\hline 143 & ----- & erythræa Gray & Red Sea \\
\hline 144 & ----- & franciscus Nardo & $?$ \\
\hline 145 & ----- & Guildingii Gray & $\begin{array}{l}\text { Cape Verde Islands, } \\
\text { Bermudas, reefs of } \\
\text { Abrohlos, Antilles, Vera } \\
\text { Cruz, Bahia }\end{array}$ \\
\hline 146 & ----- & intermedia Gray & $?$ \\
\hline 147 & ----- & marmorata Michelin & Mauritius \\
\hline 148 & ---- & miliaris Linck & $\begin{array}{l}\text { Red Sea, Mozambique, } \\
\text { Zanzibar, Mauritius, } \\
\text { Flores, Timor, Celebes, } \\
\text { Batjan, Mindanao, } \\
\text { Mondoro, north of } \\
\text { Australia, New } \\
\text { Caledonia }\end{array}$ \\
\hline 149 & ---- & mutifora Lamarck & $\begin{array}{l}\text { Red Sea, Mozambique, } \\
\text { Mauritius, Larentuka, } \\
\text { Celebes, Amboine, New } \\
\text { Caledonia, Hawaiian } \\
\text { Islands }\end{array}$ \\
\hline 150 & ----- & nodosa E. Perrier & Antilles (?), Mauritius \\
\hline 151 & ---- & pacifica Gray & $\begin{array}{l}\text { Nicobar Islands, } \\
\text { Samoan archipelago, } \\
\text { Tahiti }\end{array}$ \\
\hline 152 & ----- & pauciforis von Martens & $\begin{array}{l}\text { Anenare Islalnd near } \\
\text { Flores }\end{array}$ \\
\hline 153 & ----- & pulchella Gray & $?$ \\
\hline 154 & ---- & Rosenbergi v. Martens & Amboine \\
\hline 155 & ----- & unifascsialis Gray & $\begin{array}{l}\text { Margarita Bay, Cape } \\
\text { San Lucas, Acapuco, } \\
\text { Pearl Island, Panama, } \\
\text { Bay of Caracas (west } \\
\text { Colombia, Zorritos, } \\
\text { Realejo, Timor (von } \\
\text { Martens fide) }\end{array}$ \\
\hline & & XVII. GENUS LEPIDASTER & \\
\hline 156 & Lepidaster & teres Verrill & Panama \\
\hline
\end{tabular}


157 Cistina

$\begin{array}{ll}158 & \text { Nectria } \\ 159 & ----\end{array}$

160

16

162

163 -----

164 -----

165

166

$167 \quad-----$

168 -----

169

170 -----

171

172 -----

173

174

175
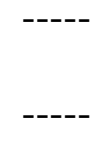

176

177
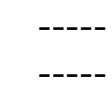

178

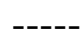

Columbiæ Gray

West coast of Colombia

XIX.GENUS NECTRIA

ocellifera Lamarck

Australian seas

ocellata E. Perrier

Bass Strait

XX. GENUS OPHIDIASTER

Agassizii E. Perrier

Juan Fernandez Island

araenatus Lamarck

?

attenuatus Gray

bicolor Lamarck

chinensis E. Perrier

Cribrarius Lütken

cylindricus Lamarck

Mediterranean

?

Canton (Chinia)

Samoan Islands

Reunion Island,

Moluccas

Floridæ E. Perrier

fuscus Gray

Germani E. Perrier

Florida Strait

Migupou

New Caledonia

glaber Peters

gracilis Gray

Mozambique

West coast of Colombia

Guildingii Gray

Saint Thomas (Antilles)

Hemprichii Müller and Trochel Red Sea

Leachii Fray

Reunion Island,

Mozambique

ophidianus Lamarack

Mediterranean, Canary

Islands, Cape Verde

Islands,? Mauritius

(Michelin fide)

Mauritius, Seychelles

Flores, Amboine,

Philippines, New

Caledonia

Margarita Bay, Cape

San Lucas, Caracas

(west Colombia

XXI. SCYTASTER

(sic) Scytaster

canariensis d'Orbigny

ægyptiacus Gray

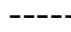

cancellatus Grube

Canary Islands

Red Sea, Mauritius, Fiji

Islands, Hawaiian

Islands

? 


$\begin{array}{lll}----- & \text { Kühlii M. T. } & \text { Java } \\ ----- & \text { Galatheæ Lütken } & \text { Indian Sea } \\ ----- & \text { Novæ Caledoniæ E. Perrier } & \text { New Caledonia } \\ ---- & \text { semiregularis v. Martens } & \text { Malaysia } \\ ----- & \text { tuberculatus, M. T. } & \text { Philippine Islands } \\ ----- & \text { variolatus } & \text { Mauritius }\end{array}$

\section{GONIASTERIDÆ}

\section{GENUS ANTHENEA GRAY}

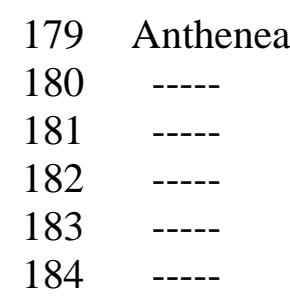

185

\author{
acuta E. Perrier \\ articulata Valenciennes \\ flavescens Gray \\ Grayi E. Perrier \\ pentagonula Lamarack \\ tuberculosa Gray \\ scaber Möbius
}

XXIII. GENUS ASTERODISCUS GRAY

West coast of Australia China, Seychelles ?

?

Hong Kong

Port Essington

(Australia)

186 Asterodiscus elegans Gray

Northeast of China

XXIV. GENUS AMPHIASTER VERRILL

187

Amphiaster insignis Verrill

La Paz

XXV. GENUS ASTEROPSIS MÜLLER AND TROSCHEL

188

Asteropsis vernicina Lamarck Panama

XXVI. GENUS CHORIASTER LŨTKEN

Choriaster granulatus Lütken

Fiji Islands

\section{GENUS CULCITA AGASSIZ}

190 Culcita

191

192

193

$$
194
$$

$-\cdot-\cdot$

195 arenosa Valenciennes

areolaa E. Perrier

coriacea Müller and Toschel

grex Müller and Toschel

Novæ Guinæ Müller and

Toschel

pentagularis Gray
Hawaiian Islands

Red Sea, Mozambique

Ibo

Mascarenes, New

Guinea 
196

---- $\quad$ Schmideliana Retzius

197

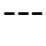

Mozambique, reefs of Attagor (Torres Strait), Fiji Islands

Zanzibar, Mozambique, Madagascar, Mauritius

Amboine, Indian seas

(?), Galapagos Islands

(Gray fide)

Saint Paul Island

XXVII (sic). GENUS DERMASTERIAS E. PERRIER

198 Dermasterias imbrica Grube

Vancouver to San

Francisco

XXVIII. GENUS GONIASTER, SENS. NOV.

199 Goniaster obtusangulus Lamarck Indian Ocean (?)

XXVIX. GENUS GONIODISCUS MÜLLER AND TROSCHEL (EMEND.)

$\begin{array}{lcll}200 & \text { Goniodiscus } & \text { capella Müller and Toschel } & \text { China } \\ 201 & ----- & \text { cuspidatus Lamarck } & \text { Moluccas } \\ 202 & ----- & \text { forficulatus E. Perrier } & \text { Migupou } \\ 203 & ----- & \text { gracilis Gray } & \text { Moluccas } \\ 204 & ---- & \text { granuliferus Gray } & \text { China } \\ 205 & ----- & \text { pencillatus Philippi } & \text { Chile } \\ 206 & ----- & \text { pleyadella Lamarck } & \text { Moluccas } \\ 207 & ----- & \text { Sebæ Müller and Toschel } & \text { Amboine, Ibo } \\ 208 & ----- & \text { seriatus Müller and Toschel } & \text { Western Australia } \\ & & & \end{array}$

209 Gymasteria carinifera Lamarck

Red Sea, Mauritius, Amboine, New Caledonia, Fiji Islands, Hawaiian Islands,

Panama

$210 \quad$---- $\quad$ biserrata v. Martens

Larentuka Island, near

Flores

$211 \quad$---- imbricata Grube

Sitka Islalnd

212 ----

inernis Gray

Panama

213 ----

valvulata E. Perrier

Galapagos Islands 


\section{GENUS HIPPASTERIA GRAY}

214 Hippasteria plana Linck

Northern seas of Europe

(Finland, coasts of

Norway and England), northern America (Duck Island, Bay of Fundy), in zone of polypiers

\section{GENUS MEDIASTER STIMPSON}

215 Mediaster æqualis Stimson

From Strait of Puget to San Francisco

\section{GENUS NIDORELLIA GRAY}

216 Nidorellia armata Gray

Margarita Bay, Cape

San Lucas, Pearl Island,

Panama, Nicaragua,

Costa Rica, Ecuador,

Zorritos, Punta Arenas,

Realejo, Point Sainte

Helene (Guayaquil)

$217 \quad$--- $\quad$ horrida Gray

218 ---- Michelini E. Perrier Mazatlan

XXXIV.GENUS PENTACEROS LINCK

$\begin{array}{lcll}219 & \text { Pentaceros } & \text { affinis Müller and Troschel } & \text { India } \\ 220 & ---- & \text { alveolatus E. Perrier } & \text { New Caledonia } \\ 221 & ---- & \text { australis Lütken } & \text { Australia } \\ 222 & ---- & \text { Caledonicus E. Perrier } & \text { New Caledonia } \\ 223 & ----- & \text { carinatus Müller and Troschel } & \text { ? Adriatic } \\ 224 & ----- & \text { Chinensis Gray } & \text { China } \\ 225 & ---- & \text { Chinensis Müller and Troschel } & \text { China } \\ 226 & ---- & \text { Cumingii Gray } & \text { Point Saint Helene } \\ & & & \text { (Guayaquil) } \\ 227 & ----- & \text { dorsatus Linck } & \text { Cape Verde Islands } \\ 228 & ----- & \text { forcipulosus Lütken } & \text { Guinea } \\ 229 & ---- & \text { Franklini Gray } & \text { Australia } \\ 230 & ---- & \text { gracilis Lütken } & \text { East Australia } \\ 231 & ----- & \text { granulosus Gray } & \text { Australia } \\ 232 & ----- & \text { Hedemanni Lütken } & \text { Billeton Island (between } \\ & & & \text { Sumatra and Borneo) } \\ 233 & ----- & \text { hiulcus Linck } & \text { Zanzibar, Mauritius } \\ 234 & ----- & \text { mammillatus Audouin } & \text { Red Sea, Mauritius }\end{array}$


Zanzibar, Madagascar, Seychelles, Mascarenes, Timor, Larentuka near Flores, Moluccas

(Amboine)

\begin{tabular}{|c|c|c|c|}
\hline 236 & ----- & nodosus Gray & Zanzibar \\
\hline 237 & ----- & nodulosus E. Perrier & Australia \\
\hline 238 & ----- & obtusatus Lamarck & $\begin{array}{l}\text { Mauritius, Philippine } \\
\text { Islands }\end{array}$ \\
\hline 239 & ----- & occidentalis Verrill & $\begin{array}{l}\text { Margarita Bay, Cape } \\
\text { San Lucas, Panama, } \\
\text { Guayaquil }\end{array}$ \\
\hline 240 & ----- & orientalis Müller and Troschel & China \\
\hline 241 & ----- & regulus Valenciennes & Pondichery \\
\hline 242 & ----- & Reinhardti Lütken & Nicobar Islands \\
\hline 243 & ----- & reticulatus Linck & $\begin{array}{l}\text { Florida, Bahama, reefs } \\
\text { of Abrohlos, Barbados, } \\
\text { Antilles, Brazil }\end{array}$ \\
\hline 244 & ----- & superbus Möbius & Sumatra \\
\hline 245 & ----- & $\begin{array}{l}\text { tuberculatus Müller and } \\
\text { Troschel }\end{array}$ & $\begin{array}{l}\text { Red Sea, east coast of } \\
\text { Africa }\end{array}$ \\
\hline 246 & ----- & turritus Linck & $\begin{array}{l}\text { Zanzibar, Mauritius, } \\
\text { Moluccas (Aamboine, } \\
\text { Ceram, Banda, Donoa, } \\
\text { Bouro), New Caledonia }\end{array}$ \\
\hline 247 & ----- & valvulatus Müller and Troschel & Australia \\
\hline 248 & ----- & $\begin{array}{l}\text { verrucosus Müller and } \\
\text { Troschel }\end{array}$ & Indian Sea \\
\hline 249 & ----- & Westermanni Lütken & Bengal \\
\hline
\end{tabular}

250 Pentangonaster aculeatus Barett (Astrogonium)

$\begin{array}{lll}251 & ---- & \text { acutus Heller } \\ 252 & ---- & \text { borealis Barett } \\ 253 & ---- & \text { dilatatus E. Perrier } \\ 254 & ---- & \text { granularis Retzius } \\ & & \text { hispidus Sars } \\ 255 & ---- & \text { inæqualis Gray } \\ 256 & ---- & \text { mammillatus Valenciennes } \\ 257 & ---- & \text { miliaris Gray } \\ 258 & ---- & \text { mirabilis E. Perrier } \\ 259 & ---- & \text { paxillosus Gray } \\ 560 & ---- & \end{array}$

North of the Atlantic

Adriatic

North of the Atlantic

New Zealand

Finland, coasts of

Norway and England

Lofoden

Amboine, New Guinea ?

New Zealand

Gulf of Smyrna

Port Essington

(Australia) 


\begin{tabular}{|c|c|c|c|}
\hline 261 & ---- & placenta Müller and Troschel & Adriatic \\
\hline 262 & --- & punctatus Lamarck & $?$ \\
\hline 263 & ---- & regularis Linck & $?$ \\
\hline 264 & --- & rugosus Hutton & New Zealand \\
\hline 265 & ---- & $\begin{array}{l}\text { singularis Müller and } \\
\text { Troschel }\end{array}$ & $\begin{array}{l}\text { Chile, Strait of } \\
\text { Magellan) }\end{array}$ \\
\hline 266 & ---- & spinulosus Gray & Philippines, Fiji \\
\hline 267 & ---- & tuberculatus Gray & Port Natal \\
\hline 268 & Pentagonaster & verrucosus Philippi & Valparaiso \\
\hline 269 & $\begin{array}{l}\text { (Calliaster) } \\
\text { Pentagonaster }\end{array}$ & Childreni Gray & Japan \\
\hline 270 & $\begin{array}{l}\text { (Calliderma) } \\
\text { Pentagonaster }\end{array}$ & Emma Gray & Japan \\
\hline 271 & $\begin{array}{l}\text { (Dorigona) } \\
\text { Pentagonaster }\end{array}$ & longimana Möbius & Malacca \\
\hline $\begin{array}{l}272 \\
273\end{array}$ & $\begin{array}{l}---- \\
----\end{array}$ & $\begin{array}{l}\text { Mülleri v. Martens } \\
\text { abnormarlis Gray }\end{array}$ & China, Japan \\
\hline 274 & ----- & Dübeni Gray & East Australia \\
\hline 275 & ----- & Fonki Philippi & Chile \\
\hline 276 & ---- & Gunnii E. Perrier & $\begin{array}{l}\text { Georgetown } \\
\text { (Australia) }\end{array}$ \\
\hline 277 & ----- & $\begin{array}{l}\text { Lamarcki Müller and } \\
\text { Troschel }\end{array}$ & \\
\hline 278 & ---- & $\begin{array}{l}\text { Luzonicus Gray } \\
\text { pulchellus }\end{array}$ & $\begin{array}{l}\text { Philippines } \\
\text { Nouvelle Hollande } \\
\text { (Iceland) }\end{array}$ \\
\hline 279 & ----- & semilunatus Linck & $\begin{array}{l}\text { Cape Verde Island, } \\
\text { Senegal, Anntilles, } \\
\text { Charleston (South } \\
\text { Carolina), Zanzibar, } \\
\text { islands of Maylasia, } \\
\text { China }\end{array}$ \\
\hline 280 & $\begin{array}{l}\text { Pentagonaster } \\
\text { (Stellaster) }\end{array}$ & Belcheri Gray & $\begin{array}{l}\text { Amboine, New Guinea, } \\
\text { north Australia }\end{array}$ \\
\hline 281 & ----- - - & Childreni Gray & $\begin{array}{l}\text { China, Japan, Formosa, } \\
\text { Australia }\end{array}$ \\
\hline 282 & ----- & granulosus E. Perrier & Australia \\
\hline 283 & ----- & Incei Gray & North Australia \\
\hline 284 & 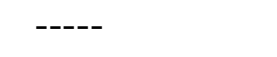 & tuberculosus v. Martens & China \\
\hline 285 & $\begin{array}{l}\text { Pentagonaster } \\
\text { (Tosia) }\end{array}$ & astrologorum M. T. & Australia \\
\hline 286 & ---- & auratus Gray & Australia \\
\hline 287 & ---- & australis Gray & Australia \\
\hline 288 & ---- & grandis Gray & Australia \\
\hline 289 & ----- & magnificus M T. & Tasmania \\
\hline 290 & ----- & nobilis Müller and Troschel & Australia \\
\hline
\end{tabular}




\begin{tabular}{|c|c|c|c|}
\hline 291 & ----- & ornatus M. T. & \\
\hline 292 & ----- & ruber Gray & Australia \\
\hline 293 & ----- & tubercularis Gray & Swan River (Australia) \\
\hline \multicolumn{4}{|c|}{ XXXVI. GENUS PORANIA GRAY } \\
\hline 294 & Porania & patagonica E. Perrier & Patagonia \\
\hline 295 & ----- & pulvillus O.-F. Müller & $\begin{array}{l}\text { Coasts of Norway and } \\
\text { Englanld }\end{array}$ \\
\hline
\end{tabular}

\section{ASTERINIDÆ}

XXXVII. GENUS ASTERINA NARDO

\begin{tabular}{|c|c|c|c|}
\hline 296 & Asterina & Burtonii Grapy & Red Sea \\
\hline 297 & ---- & calca Lamarck & Australia \\
\hline 298 & ---- & calcarata Valenciennes & Chile \\
\hline 299 & ---- & cephea Valenciennes & $\begin{array}{l}\text { Red Sea, Zanzibar, } \\
\text { Mozambique, Ibo, Java, } \\
\text { Philippines, New } \\
\text { Caledonia }\end{array}$ \\
\hline 300 & ---- & Chilensis Lütken & Peru, Chile \\
\hline 301 & ---- & coccinea Müller and Troschel & Cape of Good Hope \\
\hline 302 & ---- & coronata von Martens & $\begin{array}{l}\text { Mozambique, Moluccas } \\
\text { (Batjan, Amboine) }\end{array}$ \\
\hline 303 & ---- & Diesingi Müller and Troschel & \\
\hline 304 & ---- & exigua Lamarck & $\begin{array}{l}\text { Cape of Good Hope, } \\
\text { Natal, Mascarennes, } \\
\text { Java (Palabuan), } \\
\text { Moluccas (Bagtjan), } \\
\text { Philippines, Australia, } \\
\text { Saint Paul Island }\end{array}$ \\
\hline 305 & ---- & fimbriata E. Perrier & Reunion Island \\
\hline 306 & ---- & Gayi E. Perrier & Chili \\
\hline 307 & ---- & gibbosa Pennant & $\begin{array}{l}\text { European seas. — ? Red } \\
\text { Sea, Mozambique, } \\
\text { Mascarenes, Philippines } \\
\text { Flores, Moluccas } \\
\text { (Batjan) }\end{array}$ \\
\hline 308 & ---- & granifera Gray & Cape of Good Hope \\
\hline 309 & ---- & granulosa E. Perrier & Hawaiian Islands \\
\hline 310 & ---- & Gunnii Gray & Australia, Tasmania \\
\hline 311 & ---- & marginata Valenciennes & $\begin{array}{l}\text { Brasil (Rio Janeiro), } \\
\text { Senegal }\end{array}$ \\
\hline 312 & ---- & miniata Brandt & $\begin{array}{l}\text { Sitka Island, California } \\
\text { (Monterey) }\end{array}$ \\
\hline
\end{tabular}




\begin{tabular}{|c|c|c|c|}
\hline 313 & ---- & minuta Gray & Antilles \\
\hline 314 & ---- & modesta Verrill & Panama, Pearl Island \\
\hline 315 & ---- & Novæ Zelandiæ E. Perrier & New Zealand \\
\hline 316 & ---- & obtusa Gray & Panama \\
\hline 317 & ---- & pectinifer Müller and Troschel & Hakodadi (Japan) \\
\hline 318 & ---- & penicillaris Lamarck & $\begin{array}{l}\text { Red Sea, Java, Adenas } \\
\text { near Flores, Moluccas }\end{array}$ \\
\hline 319 & ---- & pusilla E. Perrier & Talcahuano (Chile) \\
\hline 320 & --- & regularis Verrill & $\begin{array}{l}\text { Akaroa, Australia, } \\
\text { Auckland Islands, New } \\
\text { Zealand }\end{array}$ \\
\hline 321 & & setacea Valenciennes & $?$ \\
\hline 322 & ---- & squamata Valelnciennes & Senegal \\
\hline 323 & ---- & stellaris E. Perrier & \\
\hline 324 & ---- & trochiscus Müller and Troschel & Indian Sea \\
\hline 325 & ---- & Wesseli Lütken & Barbados \\
\hline 326 & $\begin{array}{l}--- \\
----\end{array}$ & Wega Valenciennes & Red Sea, Mauritius \\
\hline \multicolumn{4}{|c|}{ XXXVIII. GENUS DISASTERINA E. PERRIER } \\
\hline 327 & Disasterina & abnormalis E. Perrier & New Caledonia \\
\hline \multicolumn{4}{|c|}{ XXXIX. GENUS GANERIA GRAY } \\
\hline 328 & Ganeria & Falklandica Gray & Falkland Islands \\
\hline \multicolumn{4}{|c|}{ XL. GENUS NEPANTHIA GRAY } \\
\hline 329 & Nepanthia & Belchderi E. Perrier & $?$ \\
\hline 330 & ---- & brevis E. Perrier & Strait of Prince of Wales \\
\hline 331 & ---- & maculata Gray & Migupou \\
\hline \multicolumn{4}{|c|}{ XLI. GENUS PALMIPES LINCK } \\
\hline 332 & Palmipes & inflatus Hutton & New Zealand \\
\hline 333 & & membranaceus Linck & $\begin{array}{l}\text { Coasts of England, } \\
\text { Channel, Atlantic, } \\
\text { Mediterranean }\end{array}$ \\
\hline 334 & --- & rosaceus Lamarck & Japan \\
\hline \multicolumn{4}{|c|}{ XLII. GENUS PATIRIA GRAY (EMEND.) } \\
\hline 335 & Patiria & crassa Gray & Australia \\
\hline 336 & ---- & ocellifera Gray & $?$ \\
\hline
\end{tabular}


XLVIII. GENUS SOCOMIA

337 Socomia paradoxa Gray

\section{PTERASTERIDÆ}

XLIV. GENUS HYMENASTER WYVILLE THOMSON

338 Hymenaster pellucidus Wyville Thomson Deep waters of the Atlantic

XLV. GENUS PTERASTER MÜLLER AND TROSCHEL

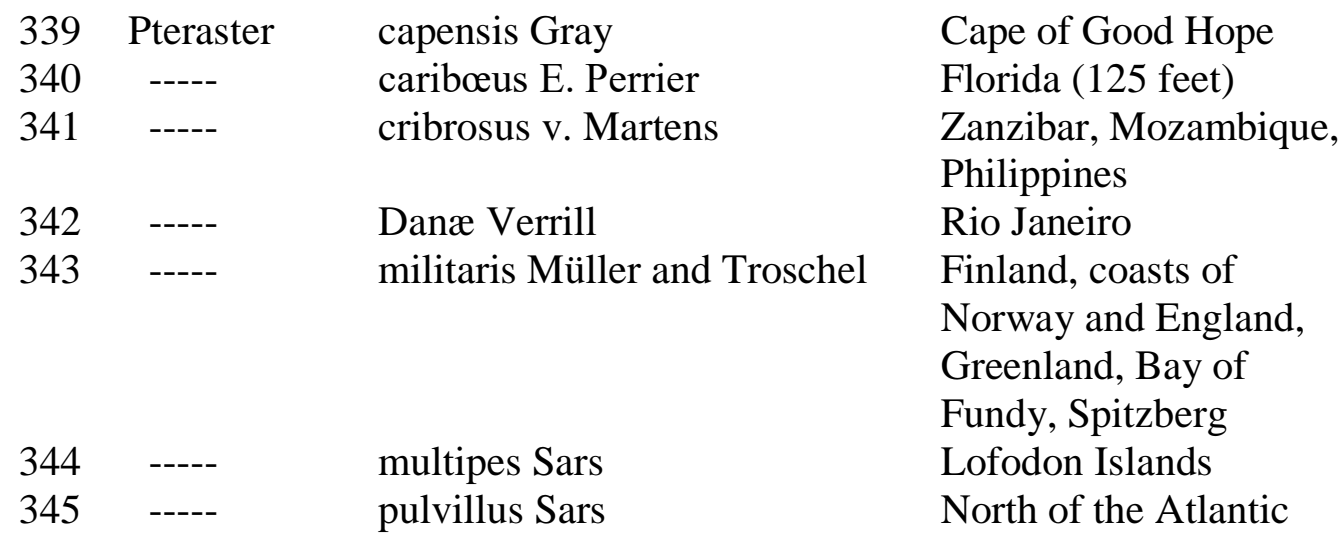

\section{ASTROPECTINID $Æ$}

XLVII. GENUS ARCHASTER MÜLLER AND TROSCHEL

\begin{tabular}{|c|c|c|}
\hline Archaster & angulatus Müller and Troschel & $\begin{array}{l}\text { Mascarenes, Java, } \\
\text { Philippines, Australia }\end{array}$ \\
\hline ------ & arcticus Sars & Finland \\
\hline ------ & bifrons Wyville Thompson & $\begin{array}{l}\text { Deep waters of the } \\
\text { Atlantic }\end{array}$ \\
\hline ------ & Christi Düben and Koren & North Seas \\
\hline ------ & hesperus Müller and Troschel & Japan \\
\hline ------ & Parelii Düben and Koren & North seas of Europe \\
\hline ------ & subinermis Philippi & Mediterranean \\
\hline ------ & tenuispinus Düben and Koren & Deep waters of Norway \\
\hline ------ & typicus Müller and Troschel & $\begin{array}{l}\text { Japan, Mollucas (Batjan, } \\
\text { Amboine), Adnares by } \\
\text { Flores, Timor, Australia, }\end{array}$ \\
\hline
\end{tabular}


New Caledonia, Tonga

Islands

Deep waters of the

Atlantic

\section{GENUS ASTROPECTEN LINCK}

\begin{tabular}{|c|c|c|c|}
\hline 356 & Astropecten & aciculares Norman & Coasts of England \\
\hline 357 & ---- & alatus E. Perrirer & $?$ \\
\hline 358 & ---- & antillensis Lütken & Antilles \\
\hline 359 & ---- & armatus Gray & Puerto Portrero \\
\hline 360 & --- & articulatus Say & Florida, Georgia \\
\hline 361 & ---- & aster Philipppe & Adriatic, Mediterranean \\
\hline 362 & ---- & aurantiacus Linné & Mediterranean, Canaries \\
\hline 363 & --- & bispinosus Philippe & Mediterranean \\
\hline 364 & --- & $\begin{array}{l}\text { brasiliensis Müller and } \\
\text { Troschel }\end{array}$ & $\begin{array}{l}\text { Antilles (Saint Vincent, } \\
\text { Brazil }\end{array}$ \\
\hline $\begin{array}{l}365 \\
366\end{array}$ & --- & $\begin{array}{l}\text { Buschii Phhilippe } \\
\text { calcitrapa Lamarck }\end{array}$ & \\
\hline 367 & ---- & Chinensis Grube & China \\
\hline 368 & --- & ciliatus Grube & Puerto Cabello \\
\hline 369 & ---- & cœlacanthus von Martens & \\
\hline 370 & --- & diplacanthus Gray & \\
\hline 371 & --- & duplicatus Gray & $\begin{array}{l}\text { Florida, Vera Cruz, } \\
\text { Antilles (Saint Vincent), } \\
\text { Brazil }\end{array}$ \\
\hline 372 & --- & $\begin{array}{l}\text { echinulatus Müller and } \\
\text { Troschel }\end{array}$ & North of the Atlantic \\
\hline 373 & --- & Edwardsi Verrill & $\begin{array}{l}\text { New Zealand, Auckland } \\
\text { Islands }\end{array}$ \\
\hline 374 & --- & ensifer Grube & \\
\hline 375 & ---- & erinaceus Gray & Guayquil \\
\hline 376 & ---- & euryacanthus Lütke & Nicobar Islands \\
\hline 377 & ---- & fimbriatus Linck & $?$ \\
\hline 378 & ---- & fragilis Verrill & Panama, Zorritos, Peru \\
\hline 379 & ---- & gracilis Gray & $?$ \\
\hline 380 & --- & $\begin{array}{l}\text { granulatus Müller and } \\
\text { Troschel }\end{array}$ & ? \\
\hline 381 & --- & $\begin{array}{l}\text { Hemprichi Müller and } \\
\text { Troschel }\end{array}$ & Red Sea \\
\hline 382 & --- & hispidus Müller and Troschel & ? \\
\hline 383 & ---- & irregularis Pennant & $\begin{array}{l}\text { Coasts of Norway and } \\
\text { England }\end{array}$ \\
\hline 384 & ---- & japonicus Müller and Troschel & Japan \\
\hline & --- & javanicus Müller and Troschel & Java \\
\hline & ---- & Johnstoni Delle Chiaje & Mediterranean \\
\hline
\end{tabular}




\begin{tabular}{|c|c|c|c|}
\hline 387 & ---- & latiradiatus Gray & Tehuantepec \\
\hline 388 & ---- & longipes Gray & Mauritius \\
\hline 389 & ---- & $\begin{array}{l}\text { longispinus Müller and } \\
\text { Troschel }\end{array}$ & Java \\
\hline 390 & ---- & Lütkeni Barrett & \\
\hline 391 & ---- & $\begin{array}{l}\text { marginatus Müller and } \\
\text { Troschel }\end{array}$ & $?$ \\
\hline 392 & ---- & Mauritianus Gray & Mauritius \\
\hline 393 & ---- & mesodiscus Linck & $?$ \\
\hline 394 & ---- & Erstedi Lütke & $\begin{array}{l}\text { Margarita Bay, Cape } \\
\text { San Lucas, Panama, } \\
\text { Realejo }\end{array}$ \\
\hline 395 & ---- & Olfersi Grube & $?$ \\
\hline 396 & ---- & paleatus Grube & $?$ \\
\hline 397 & ---- & pentacanthus Philippi & Mediterranean \\
\hline 398 & ---- & peruvianus Verrill & Peru (Payta) \\
\hline 399 & ---- & platyacanthus Philippi & Mediterranean \\
\hline 400 & & $\begin{array}{l}\text { polyacanthus Müller and } \\
\text { Troschel }\end{array}$ & $\begin{array}{l}\text { Red Sea, Australia, } \\
\text { New Zealand, Ceylon, } \\
\text { Japan }\end{array}$ \\
\hline 401 & ---- & Pressii Müller and Troschel & $\begin{array}{l}\text { Southwest coast of } \\
\text { Australia }\end{array}$ \\
\hline 402 & ---- & regalis Gray & San Blas \\
\hline 403 & ---- & regularis Linck & $?$ \\
\hline 404 & ---- & Richardi Valenciennes & Guyana \\
\hline 405 & ---- & Samoensis E. Perrier & Samoa \\
\hline 406 & ---- & $\begin{array}{l}\text { Schœnleinii Müller and } \\
\text { Troschel }\end{array}$ & Goree \\
\hline 407 & ---- & scoparius Valenciennes & Japan \\
\hline 408 & ---- & serratus Valenciennes & $\begin{array}{l}\text { Atlantic (Rochelle, Bay } \\
\text { of Biscay), } \\
\text { Mediterranean }\end{array}$ \\
\hline 409 & ---- & spatuliger E. Perrier & $?$ \\
\hline 410 & ---- & spinulosus Philippi & Mediterranean \\
\hline 411 & ---- & squamatus & Seas of the north \\
\hline 412 & ---- & stellatus Gray & \\
\hline 413 & ---- & $\begin{array}{l}\text { Tiedemanni Müller and } \\
\text { Troschel }\end{array}$ & \\
\hline 414 & & triseriatus Philippi & $\begin{array}{l}\text { Southwest coast of } \\
\text { Australia }\end{array}$ \\
\hline 415 & ---- & umbrinus Grube & Japan \\
\hline 416 & ---- & vappa Müller and Troschel & Australia \\
\hline 417 & ---- & velitaris von Martens & China \\
\hline 418 & ---- & vestita Say & Massachussetts \\
\hline
\end{tabular}


XLIX. GENUS CHÆTASTER

$\begin{array}{ll}419 & \text { Chætaster } \\ 420 & ---- \\ 421 & ---- \\ 422 & ---- \\ 423 & ---- \\ 424 & ----\end{array}$

longipes Retzius

Mediterranean

californicus Grube

California

cylindratus Möbius

Manilla

Hermanni Müller and Troschel ?

nodosus E. Perrier

Antilles

Troscheli Valenciennes

(?) Antilles

\section{CTENODISCUS}

425 Ctenodiscus

426 australis Lovén

corniculatus Linck
West Patagonia

Finland (coast of

Norway), Greenland, Frenchman's Bay (United States)

\section{GENUS LUIDIA FORBES}

\begin{tabular}{|c|c|c|c|}
\hline 427 & Luidia & alternata Say & $\begin{array}{l}\text { Antilles (Saint Thomas, } \\
\text { Tortugas) }\end{array}$ \\
\hline 428 & ---- & brevispina Lütken & $\begin{array}{l}\text { Mazatlan, Hawaiian } \\
\text { Islands }\end{array}$ \\
\hline 429 & ---- & Bellonæ Lütken & $\begin{array}{l}\text { Panama, Guayaquil, } \\
\text { Callao }\end{array}$ \\
\hline 430 & ---- & californica E. Perrier & California \\
\hline 431 & ---- & ciliaris Philippe & Mediterranean, Atlantic \\
\hline 432 & ---- & clathrata Say & $\begin{array}{l}\text { Beaufort, Charleston, } \\
\text { Cayfort (40 feet), } \\
\text { Antilles (Haiti), Rio } \\
\text { Janeiro }\end{array}$ \\
\hline 433 & ---- & Colombiæ Gray & San Blas \\
\hline 434 & ---- & debilis Grube & $?$ \\
\hline 435 & ---- & elegans E. Perrier & United States \\
\hline 436 & ---- & foliolata Grube & \\
\hline 437 & ---- & Hardwickii Gray & Indian Ocean \\
\hline 438 & ---- & maculata Müller and Troschel & $\begin{array}{l}\text { Japan, Philippines } \\
\text { (Manila), coast of } \\
\text { Coromandel - } \\
\text { Mozambique }\end{array}$ \\
\hline 439 & ---- & Sarsii Düben and Koren & North of the Atlantic \\
\hline 440 & ---- & Savignyi Audouin & Red Sea \\
\hline 441 & ---- & Senegalensis Lamarck & Senegal, Antilles, Brazil \\
\hline 442 & ---- & tessellata Lütken & $\begin{array}{l}\text { West coast of America } \\
\text { (Panama, Acajutla) }\end{array}$ \\
\hline 443 & ---- & variegata E. Perrier & Cape Breton Island \\
\hline
\end{tabular}


BRISINGIDÆ

\section{GENUS ABSJORNSSEN}

$\begin{array}{llll}444 & \text { Brisinga } & \text { coronata } & \begin{array}{l}\text { Lofoden, Feroe, coast of } \\ \text { Ireland }\end{array} \\ 445 & ---- & \text { endecacnemos Absjornssen } & \begin{array}{l}\text { Lofoden, Bergen, coast } \\ \text { of Portugal }\end{array}\end{array}$

\section{GEOGRAPHICAL ISLANDS}

It is now easy to distinguish in the various parts of the word, the more or less extensive areas that are distinctive to certain groups of species and that have the same fauna of starfish at all localities.

The most northern part of the Atlantic has a small number of species, but these species are for the most part common to all the coasts of the circumpolar regions. We can name this region arctic region. There are:

Asterias stellionura

---- polaris

Stichaster albulus

Cribrella oculata

Solaster papposus

---- endeca

Ctenodiscus crispatus

Pteraster militaris

All these species except the first two are found again in the following European zone that we can call the boreal region, but some new species are added to it. These are:

Asterias glacialis

---- rubens

Stichaster roseus

Solaster furcifer

Hippasteria plana

Pentagonasster granularis

---- hispidus

---- borealis

---- aculeatus

Porania pulvillus

Archaster Parelii

---- Christi

---- tenuispina

---- arcticus 
Astropecten irregularis

Luidia Sarsii

Brisinga coronata

---- endecacnemos

The southern part of the coasts of England and France are much less rich. However, some new specis appear and this contrast merits forming a special region that has already been designatd the celtic region. We find there:

Asterias glacialis

---- rubens

Solaster papposus

Echinaster sepositus

Cribrella oculata

Palmipes membranaceus

Asterina gibbosa

Astropecten serrratus

Luidia ciliaris

This is a fauna of transition that leads to that of the lusitanian region that can include the Mediterranean as an addition. Here are the species that we have observed in this sea up to now:

Asterias glacialis

---- tenuispina

Echinaster sepositus

Ophidiaster ophidianus

---- attenuatus

Pentagonaster placenta

---- acutus

---- mirabilis

? Pentaceros carinatus

* Asterina gibbosa

Chætaster longipes

* Astropecten aurantiacus

---- bispinosus

---- platyacanthus

---- aster

---- subinermis

* Luidia ciliaris

The species marked with an asterisk are those that have up to this day been found in the Ocean and notably at the Madeira Islands, at the Azores and at the Canaries. Some species of these island have not, to the contrary, been recorded in the Mediterranean. These are: 
Asterias madeirensis ${ }^{3}$

---- Webbbiana

Scytaster Canariensis

But it can happen that new investigations will notably decrease thse differences.

The fauna of the Atlalntic coast of America is interesting to compare with our European coasts. Cape Cope and Nantucket mark the extreme southern limit of a fauna that is not without analogy with the European boreal fauna. We find there:
Asterias Fabricii
---- borealis
---- Forbesii
---- compta
---- tenera
---- Stimpson
---- vulgaris
* Cribrella oculata
* Solaster endeca
---- papposus
* Hippasteria plana
* Pteraster militaris
*Ctenodoiscus corniculatus
*Luidia variegata

The species marked with an asterisk are common to the European and American coasts. There are six of them, with five genera. Asterias and Luidia alone are different. Again, it is necessary to note that $A$. borealis very cleary represents in this fauna our A. polaris; A. Forbesil, our A, rubens; A. tenera, our A. Mülleri' and, finally, Luidia variegata, our L. sarsii. It is thus appropriate to distinguish in the Atlantic a single boreal region that extends from the Eucropean coasts to those of America.

From Cape Cod to Florida, the fauna takes, to the contrary, a very special character, as the following list shows:

Asterias arenicola

---- compta

---- pallida

---- Stimpsoni

---- tenera

Echinaster echinophora

---- sentus

---- spinulosus

Astropecten articulatus

Luidia clathrata

\footnotetext{
${ }^{3}$ Asterias Madeirensis and Asterias Webbiana are very close to A. glacialis.
} 
Not one species is common with the coast of Europe. It is thus necessary to distinguish here a new region that is, strictly speaking, the North American region of the Atlantic.

Leaving Florida, the fauna takes a tropical character and we begin likewise to encounter species that are common with the African coast of the Atlantic, the Canary Islands and the Cape Verde Islands. This Caribbean fauna has the following constitution:

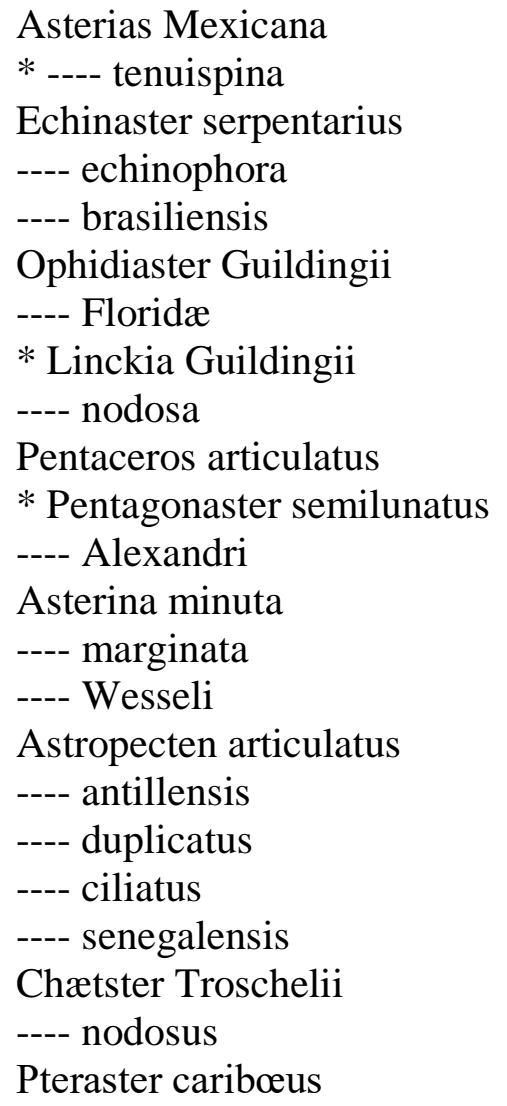

This very rich fauna contains as can be seen species of the preceding region. Some species are special to it, but five of them are common with the opposite coast of the Atlantic. This latter is, it is very necessry to say, very little known and we will have exhausted what we know in reporting, in addition to the preceding, the followingi species from the Cape Verde Islands or of Senegal:

$\begin{array}{ll}\text { Cape Verde Islands } & \begin{array}{l}\text { Ophidiaster ophidianus } \\ \text { Linckia Bouvieri } \\ \text { Pentaceros dorsatus } \\ \text { Asterina squamata }\end{array} \\ \text { Senegal } & \end{array}$

The rest of the African coast down to the Cape of Good Hope is totally unknown and we can say almost as much for the coast of South America where we find presently mentioned only the following species: 
Echinaster echinophora

---- brasiliensis

* Asterina marginata

Pteraster Danæ

Astropecten Richardi

---- brasiliensis

Luidia senegalensis

Two of these are also African. It is probable this list is very incomplete. It does not permit at the moment to characterize the fauna of this region and that will probably have to be distinguished later as the brasilian region.

The east coast (sic) of othe Anerican continent has been carefuly studied from the point of view of the distribution of echinoderms by Verrill. He has reviewed, with special care, all the documents regarding it. Here are the regions that he adopts. We modify the names in his list only those names that are duplicates and those that do not have priority. We add a small number of species that have since been encountered in those regions.

\section{Sitka Island}

Asteropsis imbricata

Asterina miniata

Solaster decemradiatus

Pycnopodia helianthoides

Asterias ochrcea

---- epichlora

\section{From the Strait of Puget to Cape Mendocino}

Mediaster æqualis

*Asterina miniata

Cribrella lævuscula

*Pycnopodia helianthoïdes

*Asterias epichlora

*---- ochracea

----- conferta

----- fissispina

----- gigantea

----- Lütkenii

---- paucispina

----- Troschelii

----- hexactis

----- Katherinæ 
3. From Cape Mendocino to Cape San Lucas

Asteropecten CErstedii

Nidorellia armata

Orcaster occidentalis

Linckia unifascialis

---- diplax

Ophidiaster pyramidatus

Heliaster microbrachia

Heliaster Kubiniji

Asterias sertulifera

----- æqualis

----- brevispina

----- capita

4. Coast of Mexico and Gulf of California

Luidia brevispina

*Nidorellia armata

----- Michelini

* Linckia unifascialis

Amphiaster insignis

* Heliaster Kubinji

5. Panamanian region

Luidia Colombiæ

Astropecten fragilis

---- regalis

---- erinacens

---- latiradiatus

Asterina obtusa

---- modesta

Gymnasteria carinifera

(?) ---- inermis

* Nidorellia armata

Pentaceros occidentalis

* Linckia unifascialis

* Ophidiaster pyramidatus

Lepidaster terres

Mithrodia Bradleyi

Echinaster tenuispinus

---- acuelatus

* Acanthaster Ellisii

* Heliaster microbrachia 
6. Ecuador and Colombia

Luidiai Bellonæ

* Astropecten erinaceus

* ---- fragilis

Nidorellia horrida

* armata

Pentaceros Cumingii

* Linckia unifascialis

---- Colombiæ

Ophidiaster Colombiæ

---- gracilis

---- pyramidatus

Ferdina Cumingii

* Acanthaster Ellisii

7. Peru

* Luidia Bellonæ (Zorritos)

* Astropecten fragilis (Zorritos)

---- Peruvianus (Paita)

* Nidorellia armata (Zorritos)

* Linckia unifascialis (Zorritos)

* Ophidiaster pyramidatus (Zorritos)

Asterina Chilensis (Callao)

Stichaster aurantiacus (Callao)

Heliaster Cumingii (Zorritos, Payta)

---- heliaster (Payta, Callao)

\section{Chile}

Asterias clavata

---- echinata

---- fulva

---- gelatinosa

---- gemmifer

---- Germani

---- lurida

---- mitis

---- spectabilis

---- varia

Stichaster aurantiacus

Heliaster helianthus

Echinaster cribrella

Ophidiaster Agassizi

Pentagonaster Fonki 


$$
\begin{aligned}
& \text {---- penicillatus } \\
& \text {---- singularis } \\
& \text {---- verrucosus } \\
& \text { Asterina chilensis } \\
& \text {---- calcarata } \\
& \text {---- Gayi } \\
& \text {---- fimbriata } \\
& \text {---- pusilla }
\end{aligned}
$$

\title{
9. Southern point of America
}

\author{
Asterias antarctica \\ ---- Cumminghami \\ ---- meridionalis \\ ---- rugispina \\ ---- sulcifer \\ Labidiaster radiosus \\ ? Acanthaster solaris \\ Porania patagonica \\ Pentagonaster singularis \\ Ganeria Falklandica \\ Ctenodiscus australis
}

The preceding lists indicate that one can distinguish four principal regions on the west coast of America. The first extends from Sitka Island to Cape Mendocino that can be called the northwest American region. The second begins at Cape Mendocino and extends to between Zorritos and Payta on the coast of Peru that can be called the mexican-panamanian region. The third contains the rest of Peru and Chile that can be called the peruvian-chilean region. The patagonian region follows the latter. These regions have few species in common. But one can, like Verrill, subdivide several of them taking into account not the species with the most extensive distribution (like Pycnopodia helianthoïdes, Nidorellia armata, Linckia unifascialis, Ophidiaster prmidatus etc.) but those that are less distributed. This is how one can distinguish the followinng districts that we have not stressed before: 1. Sitka Island District, 2. Oregonian District, 3. Californian District, 4. Panamanian District, 5. Peruvian District, 6. Chilian District, 7. Araucanian District, 8. Fuelgian District. One can also make another district for the Galapagos Islalnds whose very incompletely known fauna seems closely related to the Peruvian fauna.

We must also add that the regions accepted by Verrill appear a little too many to us, especially because further discoveries can modify notably the similarities of two adjacent districts of one of our regions.

It remains for us to consider the regions into which the Pacific can be divided. These regions can dbe divided in the following fashion;

1. The Red Sea and the west coast of Africa, including Madagascar, form a single large region with the archipelagos of the Pacific: Seychelles, Mascarenes, archipelagos of Malaysia, New Guinea, north of Australia, New Caledone and all of Polynesia except New Guinea.

2. The coasts of India and of Indo-China.

3. The coasts of China and Japan 
4. Australia and New Zealand

Two of these regions ( 3 and 4) are very imperfectly known. The three others are much better known and the two first are not without having large analogies between them, particularly the distribution of genera.

Here are the species that have been collected at the principal points of these latter regions:

\section{Red Sea}

Acanthaster echinites

Echinaster fallax

Lincia Ehrenbergi

---- multifora

---- erythræa

Ophidiaster Hemprichii

Scytaster ægyptiacus

Fromia Milleporella

Pentaceros mammillatus

---- tuberculatus

Culcita coriacea

Gymnasteria carinifera

Asterina Burtoni

---- Cephea

---- wega

? ---- gibbosa

---- pentagona

---- penicillaris

Astropecten Hemprichii

----- polyacanthus

Luidia Savignyi

2. Mozambique and Zanzibar

* Echinaser fallax

Ophidiaster Leachii

----- glaber

* Linckia miliaris

* ---- multiflora

* ---- Ehrenbergii

Scytaster variolatus

* Culcita coriacea

---- Schmideliana

---- pentagularis

* Pentacerous tuberculatus

---- hiulcus

---- muricatus

---- nodosus 
---- turritus

Pentagonaster semilunatus

Goniodiscus Sebæ

* Gymnasterias carinifera

* Asterina cephea

---- coccinea

(?) ---- coronata

* gibbosa

Pteraster cribrosus

* Astropecten Hemprichii

Luidia maculata

3. Mascarenes

Asterias borbonica

---- calamaria

---- Jehennesii (Madascar)

---- tenuispina

Valvasterias striata

Mithrodia clavigera

Ferdina flavescens

* Fromia milleporella

Linckia diplax

---- marmorata

* miliaris

* multifora

(?) ---- nodosa

Ophidiaster cylindricus

----- Leachii

---- purpureus

* Scytaster variolatus

* ---- ægyptiacus

Culcita Novæ-Guineæ

---- Schmideliana

* Gymnasteria carinifera

* Pentaceros hiulcus

* ---- mammillatus

* ---- muricatus

* ---- obtusatus

---- turritus

Asterina exigua

(?) ---- gibbosa

---- wega

Archaster angulatus

Astropecten Mauritianus 
4. Indian archipelagos

(?) Asterias tenuispina

Calvasterias asterinoïdes

* Aacanthaster echinites

Cribrella ornata

Echinaster eridanella

---- fallax

* Mithrodia clavigera

* Linckia diplax

* ---- miliaris

* ---- multifora

---- pacifica

---- pauciforis

---- Rosenbergi

* Scytaster ægyptiaeus

----- tuberculatus

* ---- variolatus

* Culcita Novæ Guineæ

* ---- pentagularis

* ---- Schmideliana

Goniaster obtusangulus

Goniodiscus cuspidatus

---- gracilis

---- pleyadella

* ---- Sebæ

* Gymnasteria cariifera

---- biserrata

* Pentaceros muricatus

* ---- obtusatus

---- superbus

* ---- turritus

Pentagonaster inæqualis

* semilunatus

---- (Stellaster) Belcheri

* Asterina exigua

* ---- gibbosa

* ---- penicillaris

* Archaster angulatus

* ----- typicus

Astropecten javanicus

---- polyacanthus

* Luidia maculata

* Pteraster cribrosus 
As can be seen by the number of asterisks that indicate species in common, these diverse locaties, in spite of some secondary differences, should be considered as forming a single and very vast region of zoological geography. The closest afinities unite the faunas they contain. This is what can be called the Pacific region.

The species of India itself are still less numerous.

Indian and Indo-China

(?) Asterias rubens (Sp. affin)

Fromia indica

Pentaceros affinis

---- regulus

---- Reinhardti

---- verrucosus

---- Westermanni

Dorigona longimana

Astropecten euryacanthus

Luidia Hardwickii

But it is sufficient to glance at this list and compare it with the preceding to see that we are in a completely different region. If the genera still appear very close, the species are absolutely distinct and it is necessary to make the same remark on the following very long list of species of China and Japan.

China and Japan

Asterias japonica

? ---- rubens

* tenuispina

Solaster (?) gracilis

Fromia japonica

Metrodira subtilis

Ophidiaster chinensis

Anthenea articulata

Asterodiscus elegans

Goniodiscus capella

---- granuliferus

Pentaceros chinensis

---- orientalis

Calliaster Childreni

Calliderma Emma

Dorigona Mülleri

Pentagonaster semilunatus

Stellaster Childreni

---- tuberculosus

Asterina pectinifer 


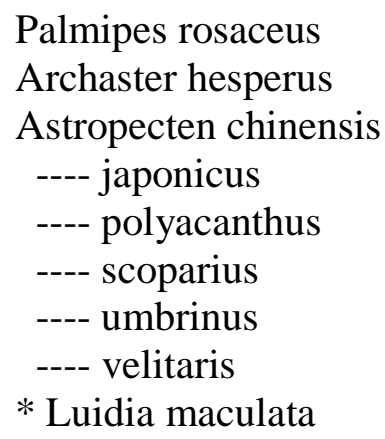

We are led in the same way to constitute two new regions, the coasts of Australia except the northern coast and neighboring islands, including New Zealand, not forming a less distinct region, as shown in the following list:

Australia — New Zealand

* Asterias calamaria (Australia and New Zealand)

---- fungifera

---- globifera

---- granifera

---- mollis (New Zealand)

---- polyplax

---- scaber (New Zealand)

* ? ---- tenuispina

Stichaster australis (New Zealand)

Cribrella ornata (New Zealand)

Echiinaster falax (New Zealand)

Stichaster decanus

Nectria ocellata

Anthenea acuta

---- tuberculosa

Goniodiscus seriatus

Pentaceros australis

----- Franklinii

----- gracilis

----- granulosus

----- nodulosus

Pentagonaster miliaris (New Zealand)

---- paxilllosus

---- rugosus (New Zealand)

---- Dübeni

---- pulchellus (Australia and New Zealand)

---- (Stellaster) granulosus

---- Incei

---- (Tosia) astrologorum

---- auratus 
---- australis

---- grandis

---- magnificus

---- nobilis

---- Pentagonaster (Tosia) ruber

---- tubercularis

Asterina calcar

---- exigua

---- Gunnii

---- regularis (Australia and New Zealand)

Palmipes inflatus (New Zealand)

Patiria crassa

Astropecten Edwardsi (New Zealand)

---- polyacanthus

---- triseriatus

---- vappa

We thus have here a fauna totally distince from those we have encountered up to here, and that has only distant afinities with the nearest faunas. A single species is common with the Cape of Good Hope.

New Zealand has three species common with Australia. All connect it with the Australian region but it is necessary to note that it is different from it in some regards. It is probable, moreover, that with a better study of the same fauna of the coast of Australia, we would be able to distinguish districts similar to those we have seen on the American coasts.

We have thus definitivey distinguished the four following regions in the Pacific:

1. Indo-Pacific Region

2. Indian Region

3. Chino-Japonese Region

4. Australian Region

We know nothing of the southern and antarctic regions, which without doubt have their own special fauna. 